\title{
CONSIDERACIONES CRITICAS SOBRE LA REGULACION DEL DELITO DE ABORTO EN EL ANTEPROYECTO DE NUEVO CODIGO PENAL ELABORADO POR EL FORO DEL MINISTERIO DE JUSTICIA
}

Prof. Dra. Maria Inés Horvitz. L. Prof. Miguel Soto P.

Introducción; I. Ratificación de la opción legislativa y politico-criminal iniciada con la dictación de la Ley 18.826 y ausencia total de debate sobre la posible introducción en nuestro ordenamiento jurídico de modelos regulativos comparados que admiten la impunidad del aborto; II. Diferencias en la determinación de la actividad típica que pueden generar relevantes problemas interpretativos, y que dicen relación con lo protegido con el delito de aborto, y el ámbito al que se extiende la protección penal de la vida a este título de incriminación; III. Conservación de la punibilidad agravada del tercero que comete aborto a una mujer que consiente en ello, sin fundamento para la agravación; IV. Ausencia de diferenciación en la punibilidad de las conductas del facultativo y en hipótesis de autoría y de participación; $V$. Ausencia de tipificación de las lesiones dolosas cometidas en contra del nasciturus, con los consiguientes problemas de delimitación entre el primer y segundo nivel de protección de la vida humana; VI. Problemas que plantea la mantención de la criminalización de, al menos, un supuesto de aborto imprudente. Alternativas político-criminales más plausibles; Anexo: Disposiciones de la Propuesta Anteproyecto de Código Penal chileno; Bibliografía.

\section{INTRODUCCION}

De la sola lectura comparada de la propuesta de regulación sobre el delito de aborto y de la regulación actualmente vigente salta a la vista que la propuesta de anteproyecto de Código Penal (en adelante, PACP) apenas introduce modificaciones al Código Penal vigente en esta materia, poniendo de manifiesto una voluntad consciente y deliberada de no innovar en un área punitiva muy polémica y en la que se parte de la presunción -a nuestro juicio equivocada y en todo caso, en este nivel, no determinante ${ }^{1}$ - de que no existirá consenso, ni en la opinión pública, ni en el Parlamento ${ }^{2}$ para introducir una reforma relevante ${ }^{3}$.

\footnotetext{
* Abogado, Doctora en Derecho por la Universidad Autónoma de Barcelona, Directora del Centro de Estudios de la Justicia, Profesora Asociada de Derecho Penal en la Universidad de Chile.

* Abogado, Magíster en Derecho, Profesor Asistente de Derecho Penal en la Universidad de Chile.

${ }^{1}$ En el plano "pre-legislativo", en el que se mueve la Propuesta de Anteproyecto de Código Penal (PACP) en comentario, las consideraciones relevantes - determinantes- no deberían ser las relativas a supuestas, contingentes y coyunturales mayorías político-legislativas -en todo evento relevantes, precisamente, en sede legislativa- sino, y en su lugar, las atingentes al "merecimiento de pena" y a la "necesidad de pena" (sobre dichos conceptos, vid., Luzón,1995; Romano, 1995 y Da Costa, 1995), que en todo caso, por el carácter propositivo, de orientación a las consecuencias, de la teoría Jurídica en general y de la jurídico-penal en particular, involucran propuestas de carácter "político (- criminal") Cfr., en general, Teubner, 1987; Calsamiglia, 1993 y Garzón, 1993 y en el ámbito propiamente penal, Schünemann, 1991, esp. pp. 712 y s.; De Figueiredo, 2001, esp. pp.16 y ss.; Palazzo, 1997, pp. 695 y ss., 714 y ss. y 730 y ss.; Díez R., 2003, pp. 109 y ss., 136 y ss. y 165 y ss. y
} 
Horvitz y Soto - Consideraciones críticas sobre la regulación del delito de aborto...

bibliografía ahí cit.. Vid., también, bibliografía cit. supra y cit. notas. 2, 3 y 13. En relación al aborto se superponen, como en pocos otros ámbitos, consideraciones puramente morales, y/o derechamente religiosas, que es necesario articular en términos coherentes con la secularización del Estado de Derecho contemporáneo. Sobre ello, vid., Laporta, 1989, pp. 234 y ss.; Dworkin, 1994, pp. 196 y s., 202 y ss. y 209 y ss.; Habermas, 1991, pp. 55 y ss.; 1992, pp. 56 y ss.; 1994, pp. 535 y ss. y ,sintéticamente, 2002 , pp. 38 y ss. y Carassale, 2005, pp. 11 y ss., 51 y ss., 127 y ss. y 189 y ss.. La "secularización" del Estado, en sentido amplio, es un problema vinculado, pero analíticamente independiente, del relativo a la rematerialización de la Constitución en el marco del denominado "Estado Constitucional". Sobre el concepto de Estado y su evolución, vid., sintéticamente, con abundante bibliografía, Zolo, 2003, esp. pp. 21 y ss.; Costa, 2003, pp. 91 y ss.; Gozzi, 2003, pp. 263 y ss.; Böckenforde, 2000, pp. 17 y ss. y para la referida rematerialización, Ferrajoli, 2003, pp. 354 y ss. vid., también, los trabajos reunidos en Elster / Slagstad, 1999 y en Carbonell, 2005. Críticamente, sobre el rendimiento del llamado "lenguaje de los derechos" y del denominado "neoconstitucionalismo", Atria, 2000, pp. 111 y ss.; 2003 a, pp. 107 y ss., esp. 117 y ss.; 2003 b, pp. 63 y ss. y, sintéticamente, 2005, pp. 19 y ss.. En el ámbito del aborto, un problema es establecer si (como implícitamente lo postula la PACP) se trata de una práctica inmoral (vid., p. ej. Vives, 1957, pp. 228 y s,. y 233 y ss.; Ugarte, 1993, pp. 15 y 17, 2006, pp. 313 y ss.). Otro distinto es el establecer si esa conducta inmoral debe ser considerada antijurídica (Barros, 2001, p. 27), siempre y en todo caso -como lo establece la PACP- o sólo en algunos casos y, en fin, si dicha conducta inmoral y antijurídica debe ser considerada merecedora de pena y, por ende, en abstracto y en principio, necesitada de pena, punible. Sobre la exclusión, en las indicaciones o en el plazo, de una antijuridicidad puramente penal, sin exclusión de la antijuridicidad general, vid., Laurenzo, 1990, pp. 289 y ss. y 327 y ss. y, 1997, adoptando en definitiva una solución que sigue a Bacigalupo, 2004, pp. 371 y ss.. Sobre dicha distinción en general, vid. supra nota 30. Dicha distinción fue establecida en Alemania para el aborto por el Tribunal Constitucional. Cfr., Zoder, 1996; Bacigalupo / Gropengieber, 1996; Bascuñán, 2001, pp. 230 y ss.; Jakobs, 2004 y, sintéticamente, Roxin, 2004, pp. 1194 y s.. En las consecuencias prácticas, una situación semejante se da en Estados Unidos a partir de "Harris v/s McRae". Cfr., C. Mackinnon, 2005, pp. 54 y s.; Holmes, 1999, pp. 80 y ss., esp. 80 n. 83. La distinción es relevante por cuanto de ella depende que los Servicios de Salud Pública cubran la intervención abortiva, en aquellas hipótesis en las que se ha despenalizado la práctica del aborto -plazo o indicaciones--; si la misma sigue siendo antijurídica, entonces el Estado no puede participar en su realización y los costos de la intervención serán íntegramente de cargo de la propia mujer embarazada. Para la situación en Alemania con anterioridad al año 1995, vid., Gössel, 1978; Roxin, 1978; Hirsch, 1982; Steiner, 1993 y Bascuñán, 2001, pp. 224 y ss. En general, para la problemática político-criminal en torno del aborto y para las distintas soluciones propuestas, vid., Romano / Stella, 1975; Roxin, 1976; Baumann, 1978; Huerta, 1979; Landrove, 1980; Arroyo, 1980; Beristain, 1981, desde una perspectiva católico-liberal; Cerezo, 1982, contra la solución del plazo y a favor de un sistema acotado de indicaciones; ídem, G. Rodríguez M., 1987; Da Costa, 1989; Díez, 1984 a), a favor de la solución del plazo; en definitiva, ídem, Farrell, 1985, pp. 97 y ss.; Conley/ Mackenna, 1988, contra "Roe v/s Wade"; Heymann/Barzelai, a favor de "Roe v/s Wade"; Eser, 1989 y 1999, a), b) y c), con una amplia revisión crítica de las soluciones en disputa; Phelps, 1988; Romeo, 1992; 1994, pp. 290 y ss., 2004 a), inclinándose, en definitiva, por una solución de indicaciones; Carbonell, J. C., 1989 y 1991; Carbonell, M., 2003; Cuerda, 1983 y 1986, por una amplia despenalización; ́́dem, Ferrajoli, 1999; 2003 y, esp. 2002; De Figueiredo, 1999, pp. 167 y ss.; Luzón, 2002; Godinho, 2005, por una solución de indicaciones. Críticamente respecto del rendimiento de una solución de indicaciones y a favor de la solución del plazo, Ropero, 2003, pp. 211 y ss.. Desde una perspectiva constitucional, Ruiz, 1990; Bascuñan, 2001, pp. 212 y ss. y Díaz, 2004. Imprescindible, Dworkin, 1994, esp. pp. 136 y ss., 157 y ss. y 194 y ss.. En favor de una amplia despenalización, desde una perspectiva de género, C. Mackinnon, 1995, pp. 329 y ss.; Pitch, 2003, pp. 75 y ss.; Zaffaroni, 2000, pp. 34 y s.; Baratta, 2000, pp. 63 y s.; Larrandart, 2000, pp. 100 y 
s.; Facio, 1999, pp. 106 y s.; Acosta, 1999, p. 670 y 673 y s.; Fries / Matus, 1999, pp. 698 y ss. y, más ampliamente, 2000, esp. pp. 33 y ss. y 83 y ss.. Para la jurisprudencia española reciente, Fernández, 2004, pp. 98 y ss.

2 Para algunos antecedentes, muy pocos, de la discusión en Chile sobre el problema del aborto y su penalización, vid., Weisner, 1982; los distintos trabajos recogidos en Requena, 1990; Casas, 1993; Fries / Matus, 1999, pp. 687 y ss.; 2000, pp. 82 y ss.; Lagos, 2001 y esp. Herrera, 2004, esp. pp. 144 y ss. En relación a la decisión de tipificar el aborto como delito, en todos los casos y sin excepción alguna, como lo postula la PACP, no puede dejar de considerarse, de un lado, la resistencia contrafáctica que los teóricos -los técnicos-- y los legisladores deberían oponer al denominado "moralismo legal", que postula elevar a la categoría de ley la llamada "moral positiva", por el solo hecho de ser tal (sobre ello, sintéticamente, vid. Teubner, 1987, esp. pp. 101 y ss.; Laporta, 1989, pp. 257 y ss.; Habermas, 1987, pp. 72 y ss.; 1991, pp. 65 y ss.; 1992, pp. 60 y ss.; Tungendhat, 1991 pp. 151 y ss.; y bibliografía ahí citada) y, del otro, y en íntima relación con lo anterior, que en materia penal un disenso, sólidamente fundado, bastaría para que entre a jugar el "principio pro libertatis". Cfr., Hart., 1968 pp. 6 y ss.; Romano, 1985, pp. 421 y ss.; Vives, 1995 a), Fioravanti, 2001, pp. 13 y ss.; Donini, 2003 a) y b). Vid. también, Cattaneo, 1970, pp. 56 y ss., 214 y ss. y 552 y ss.. Feuerbach, (1798), 1972, pp. 23 y ss. y 48 y ss. y (1847), 1989, pp. 58 y 64. En una muy somera síntesis, puede señalarse que la discusión ética circula por dos carriles no incompatibles entre sí; de una parte, el relativo al "status" (¿ontológico?) del embrión, que permitiría discernir si en función a ese "status" el "nonato" goza de un reconocimiento moral idéntico o análogo a los ya nacidos y es merecedor, por ende, de una protección equivalente (vid., Farrell, 1985, pp. 32 y ss. y Singer, Hoerster y Maturana, cit. supra); de otra parte y eventualmente con relativa independencia de lo anterior, el atingente a cómo debe resolverse el conflicto entre el interés en la vida del "nasciturus" y los derechos de la madre afectados y limitados de manera significativa con el embarazo. Sobre ello, vid., de una parte, en una postura radical, que admite incluso la legitimidad del infanticidio en muy circunscritas hipótesis, Singer, 1995 y 1996 y Hoerster, 1982, b) y c). y de otra parte, desde perspectivas católicas, progresivamente más liberales, Vives, 1957, pp. 231 y ss.; Ugarte, 1993 y 2006, pp. 225 y ss. y 313 y ss.; Beuchot, 2001; Doncel, 2001 y Beristain, 1981. En relación al conflicto entre la vida del "nonato" y la autonomía de la madre, vid., de un lado, Thomson, 1977 y 2001; Farrell, 1985, pp. 18 y ss. y Bascuñán, 2004 a), pp. 173 y ss. y, del otro, Finnis, 1977; Possenti, 1988; Marquis, 2001 y Ugarte, 2006, pp. 328 y ss.. En general, para toda la problemática, vid., Dworkin, 1994, pp. 44 y ss. y 93 y ss.; Foot, 1994; Ollero, 1996, pp. 89 y ss., Werthner, 2001, Wicclair, 2001; Vásquez, 2004 y 2005; Valdés, 1999, 2000 y 2001 a) y b); Eser, 2000 a); Ferrajoli, 2002 y coincidiendo con este último en el criterio para establecer desde qué momento del embarazo hay algo digno de protección, Maturana, H. 1991; tangencialmente, Peris, 1995, pp. 103 y s., Femeniá, 1999, pp. 125 y ss. y 211 y ss.; Brock, 2000; Habermas, 2002, pp. 46 y ss. e infra notas 3 y 11.

${ }^{3}$ La tesis de la PACP, importa negarle toda relevancia a los derechos de la mujer -en su mejor interpretación, distintos de la vida- limitados por el embarazo para, en su lugar, afirmar la absoluta e incondicionada preeminencia de la protección de la vida del "nonato". Una solución tan radical es absolutamente excepcional en el Derecho comparado, que en mayor o menor medida (plazos, solución amplia de indicaciones, solución restringida de indicaciones), le reconoce relevancia a los derechos de la mujer, permitiendo que en determinadas hipótesis, en abstracto éstos primen sobre la vida del "nasciturus". Cfr. supra nota 2, in fine, e infra notas 32 y 34. En rigor lo que marca cualquier aproximación razonable a la problemática del aborto y a los límites de su prohibición penal, es precisamente el conflicto entre el interés en la vida del que está por nacer y los derechos de la mujer que se ven severamente afectados por el embarazo. Sobre ello, en la dogmática nacional, vid. por todos, Bascuñán, 2004 a) y 2004 b) e infra notas 11 y 37. En el marco de la tesis de la Propuesta debe estimarse, o bien una incoherencia, o bien un reconocimiento de sus limitaciones, de un lado, la menor penalidad del aborto, respecto del homicidio y, del otro, la mayor 
Horvitz y Soto - Consideraciones críticas sobre la regulación del delito de aborto...

Vale decir, en la materia que nos ocupa la PACP evidencia:

a) de un lado, su carácter de "Proyecto Oficial o Gubernamental" (no de Anteproyecto elaborado por académicos especialistas que proponen la mejor regulación desde una perspectiva técnica y político-criminal), esto es, una propuesta regulativa que prefiere mantener la ortodoxia en materias políticamente complejas dejando prácticamente inalterada la opción tradicional del Código Penal, coincidente -en esta materia- con la postura oficial de la Iglesia Católica que defiende una penalización total del aborto provocado sin ningún tipo de excepciones directas; $y,{ }^{4}$

penalidad del aborto sin consentimiento en relación al autoaborto y al aborto con consentimiento de la embarazada, vid. infra, nota 4. El inmovilismo -relativo, infra, nota 6- de la propuesta y la reducción a la intrascendencia de la participación de teóricos en procesos pre-legislativos que ello importa, puede quizás invocar en su favor, de una parte, que las decisiones relativas a la "criminalización primaria", son "puramente políticas" y que, por ende, en relación a ellas, el único rol que le compete a la doctrina es el exclusivamente "técnico", de formular en forma técnicamente correcta el proyecto de legislación que recepciona esa decisión política. (Sobre esa opción, críticamente, Pulitano, 2001; Díez, 2003; Alcácer, 2003; Donini, 2003 b) y Fiandaca, 2003); de otra parte, podría esgrimir que respecto de la protección de la vida del "nonato" concurre una "obligación constitucional de tutela penal", ineludible para el legislador. Sobre tales polémicas obligaciones, vid., Fiandaca, 1982; Pulitano, 1983; Alvarez, 1991; De Figueiredo, 1999, pp. 171 y s.; Muñoz, 2001 y Mañalich, 2004. Naturalmente, en cualquier plano en que se lo plantee, incluido el "pre-legislativo", la discusión en torno del aborto es una discusión valorativa que no puede ser resuelta con "criterios puramente técnicos"; ahora bien, si ello es así, lo razonable, lo exigible, es que tales opciones morales o puramente políticas se expliciten y no se disfracen, como implícitamente hace la propuesta, de soluciones avalorativas, "puramente técnicas".

${ }^{4}$ Esta tesis es absolutamente dominante, sino unánime, en la, por lo demás muy abundante, doctrina constitucional chilena atingente al tema. Cfr. Mohor, 1989; Núñez, 1997; Cea, 2004, pp. 95 y ss. y la bibliografía cit. por Bascuñán, 2004 a), p. 157, nota 33. En el ámbito propiamente penal esta misma tesis es sustentada, por Rodríguez C., 1992. Sobre la posición de la teología moral católica, vid., Vives, 1957, pp. 227 y ss., esp. 235 y ss.; críticamente, Farrell, 1985, pp. 64 y ss.; Ugarte, 1993 y 2006, esp. pp. 313 y ss.; Montano, 1997, pp. 409 y ss., esp. 412 y ss.; Foot, 1994, críticamente; ídem, Hoerster, 1992 c); Valdés, 2000; Beuchot, 2001 y Bascuñán, op. ult. cit., pp.152 y ss., esp. 154, antes nota 1. Lo que, sin embargo, no explican quienes sostienen esta postura es la razón de la menor penalidad del aborto respecto del homicidio; en efecto, si la vida del concebido tiene el mismo valor que la del nacido ("el embrión es uno de nosotros", vid., Flamigi, 2001, pp. 103 y ss.), entonces las penas del aborto y el homicidio deberían ser similares. Más aún, debería brindársele al "nonato" una protección análoga a la del ya nacido respecto a los atentados culposos a su vida y a los atentados dolosos o culposos a su salud e integridad corporal; tipificando, consecuentemente, no sólo el aborto imprudente, sino también las lesiones dolosas e imprudentes al feto, incluidas, en todos los casos, las causadas por la propia mujer embarazada. Así, Montano, 1997, p. 414. Vid., infra, nota 36. De otro lado, con esa tesis, también carece de explicación la menor penalidad del autoaborto y del aborto consentido respecto del aborto sin el consentimiento de la mujer embarazada, diferencia de penalidad que desde antiguo se explica en función de la "lesión simultánea a la personalidad de la mujer", que va envuelta en el segundo y no en el primero. Cfr., Feuerbach, (1847), 1989, p. 260, pgr. 394. y Merkel, s/f., II, p. 37. 
b) del otro, la total ausencia de una investigación empírica que sirva de respaldo a la solución legislativa propuesta; en suma, se trata de una política criminal inmovilista e injustificadamente conservadora, construida a partir de suposiciones no contrastadas ${ }^{5}$.

Por el contrario, las escasas modificaciones introducidas, más allá de sus discutibles consecuencias dogmáticas, suponen en su lectura global un tratamiento punitivo más riguroso de estos delitos que, en lo sustancial, se corresponde con la orientación político-criminal iniciada por la Ley $\mathrm{N}^{\circ} 18.826$ que, como es sabido, derogó la indicación terapéutica como causal de exclusión de la responsabilidad penal a título de aborto existente en el Código Sanitario antes de 1989.

Por consiguiente, la PACP peca por defecto y por exceso, pues resulta difícilmente explicable que a estas alturas de la discusión nacional y comparada en torno a la protección penal de la vida del nasciturus, se mantenga inmodificada la regulación punitiva del Código Penal de 1875 en este ámbito y junto con ello se ratifique y legitime la redacción conferida al artículo 119 del Código Sanitario por la Ley $\mathrm{N}^{\mathrm{o}} 18.826^{6}$.

A fin de efectuar una exposición sistemática de las críticas a la propuesta del Foro dividiremos las mismas conforme a los siguientes criterios:

i. Ratificación de la opción legislativa y político-criminal iniciada con la Ley 18.826, dictada en las postrimerías de la dictadura militar y ausencia total de debate sobre la posible introducción en nuestro ordenamiento jurídico de modelos regulativos comparados que admiten la impunidad del aborto consentido; en ciertos casos, ampliamente en la primera fase del desarrollo del feto (por reconocerse el predominio del derecho de autodeterminación reproductiva de la mujer ${ }^{7}$ por sobre la vida del nasciturus) o a través del más conservador sistema de indicaciones (terapéutica, ética, embriopática y social) ${ }^{8}$;

\footnotetext{
${ }^{5}$ En efecto, entre los antecedentes de la PACP no se cita ningún tipo de investigación empírica del fenómeno regulado, como tampoco ocurrió con su antecedente la Ley 18.826. En ambos casos, parece tratarse de una cuestión de fe y moral católica: carecería de sentido una exigencia laica y desacralizada de respaldo empírico que, de existir, nada podría modificar.

${ }^{6}$ Implícita, pero inequívocamente, la PACP viene a ratificar la discutida --Bascuñán, 2004 a), pp. 173 y ss.-- y discutible -cfr., notas. 8, 9, 11, 19, 29, 30 y 32-- legitimidad constitucional de la Ley 18.826, pues representaría un pronunciamiento legislativo sobre una materia directa, inequívoca e inmediatamente alcanzada por el contenido regulativo de dicha Ley, que no la modifica y, por ende, la estima ajustada a la Constitución. Lo anterior, a fortiori, es particularmente efectivo cuando dicha Ley aparecería respaldada por la legitimación adicional de fundarse en un Proyecto elaborado por expertos, en base a criterios técnicos. Vid., infra, nota 31.

${ }^{7}$ La expresión, ha hecho fortuna como adecuada síntesis de la relación entre las restricciones a su autonomía que para la mujer supone el embarazo y la facultad que ésta tiene de subordinarlas en beneficio del "nasciturus". Sin embargo, puede recurrirse también, directamente, a la igualdad como derecho en conflicto, pues es obvio que con ocasión del embarazo la mujer debe soportar una
} 
Horvitz y Soto - Consideraciones críticas sobre la regulación del delito de aborto...

ii. Deficiencias en la determinación de la actividad típica que pueden generar relevantes problemas interpretativos, y que dicen relación con lo protegido con el delito de aborto, y el ámbito al que se extiende la protección penal de la vida humana a este título de incriminación';

restricción sin parangón de sus derechos fundamentales, discriminación que sólo estará justificada y será exigible coercitivamente dentro de límites muy definidos, vinculados a las restricciones connaturales al embarazo y en la medida de las mismas. Cfr., Roxin, 1997, 16 / 69, p. 709. Fuera de los alegatos de género, argumenta en este sentido, Burt, 2000, pp. 466 y ss. Vid., también, infra, nota 32 y bibliografía ahí cit. y, en general, de un lado, Laporta, 1985; Alegre, 2001, pp. 92 y ss. y Solozábal, 2005 y, del otro, críticamente sobre los presupuestos y verdadero rendimiento de los argumentos fundados en la igualdad, en el marco de un cuestionamiento más amplio de la lógica de los derechos y la justicia constitucional como límites a la política, Atria, 1997, pp. 61 y ss. y 95 y ss. y 2000, pp. 124 y ss. y 137 y ss. La restricción de la autonomía y autodeterminación de la mujer con ocasión del embarazo resulta evidente y dará lugar a un conflicto tan pronto como ella no desee la continuación del embarazo; en esta hipótesis, incluso antes que el derecho de la mujer al libre desarrollo de la personalidad, entra a jugar su dignidad como persona, que se opone a su consideración como mero recipiente de la vida del "nasciturus", esto es como mero instrumento de procreación. En todo evento, la prohibición de abortar no importa sólo la obligación de omitir dar muerte al "nasciturus", sino también y, además, la obligación de soportar la intensa restricción de sus derechos (ahora sí, inequívocamente tales y de rango constitucional) que es connatural al embarazo; vale decir, no es sólo la obligación de no matar, sino que es también la obligación de soportar.

${ }^{8}$ Sobre dicho sistema, vid., Roxin, 1976 y 1980; Baumann, 1978; Huerta, 1979,; Cerezo, 1982; Arroyo, 1986; críticamente, Cuerda, 1983 y 1986; Da Costa, 1984; Rodríguez M., 1987; Hirsch, 1982; Grosso, 1984; Díez, 1989 b) y c); Eser, 1989 y 1999, b), Gimbernat; 1990, pp. 59 y ss. 66 y ss. 73 y ss. y 76 y ss.; Carbonell M., 1991; Luzón, 1991 a) y 2002; Núñez, 1992; Romeo, 1992; 1994, pp. 290 y ss. y 2004 a), pp. 181 y ss.; Jorge Barreiro, 1993 - 1994; Vives, 1995 a); Nuñez, 1999, pp. 318 y ss.; De Figueiredo, 1999, pp. 166 y ss.; García, 2004, pp. 81 y ss.; Feijoo, 2003, pp. 307 y ss. y, críticamente, Ropero, 2003, pp. 211 y ss., esp. 222 y ss.

${ }^{9}$ Incertidumbre que no sólo atinge al problema obvio del momento en que se inicia la protección penal a título de aborto -infra $\mathrm{N}^{\circ} 2$-, sino también y en no menor medida, al relativo a su término vid., infra, nota 37 y bibliografía ahí cit.. En relación al problema, de suyo complejo, de la cesura entre aborto y homicidio (en función del parto y/o del nacimiento y/o de la autonomía en las grandes funciones vitales), el caso que se discute en la doctrina comparada y que ha devenido en verdadera piedra de toque del problema es el relativo a las maniobras realizadas sobre el feto, durante el parto, que resultan en lesiones o la muerte de la víctima después de concluido inequívocamente el parto, producido ya el nacimiento, dentro del ámbito indiscutiblemente abarcado por los tipos penales de homicidio y lesiones. ¿A qué título se sanciona la conducta? Sobre ello vid., por muchos, Farré, 1999; Silva, 2001; Peñaranda, 2003; Mendoza, 2005 y bibliografía ahí cit.. El problema teórico subyacente es encontrar un punto en el proceso continuo que es la vida, -vid., Valenzuela, 2003, pp. 164 y s.- en el que una de las modificaciones (puramente cuantitativas) que se producen en su transcurso pueda entenderse dotada de una significación cualitativa de entidad tal que justifique el tratamiento notablemente diferenciado que el ordenamiento jurídico le da al período que lo sucede respecto del que lo precede. Vid., infra, notas 10 y 37; Peñaranda, 2003, pp. 208 y ss.; Mendoza, 2005, pp. 1597 y ss. y más en general, para la relevancia ética del punto, vid. Singer y Hoerster cit. supra, nota 2 y Vives y Ugarte, cit. infra, nota 16. En todo evento, el hito al que tradicionalmente se ha recurrido al efecto en el ámbito jurídico, el nacimiento, tampoco es útil para ello; de un lado, porque el nacimiento es entendido -al igual que el parto- como un proceso dentro del cual cabe distinguir un comienzo, una etapa intermedia y una conclusión -cfr., p. ej., de un lado, Feuerbach (1847), 1989, p. 260 y Fuenzalida, 1883, pp. 113 y ss. y, del otro, Del Río, 1935, pp. 370 y s -con lo que la referencia al nacimiento, lejos de solucionarlo, 
traslada el problema -cfr., infra. notas 36 y 37 y bibliografía ahí cit. y Mezger, 1958, pp. 32 y s. y 58. De otro lado, la referencia al nacimiento para determinados efectos jurídicos, pasa a tener un carácter evidentemente "artificial" y puede, por ello, ser sustituida por otros hitos igualmente "artificiales", que resulten más funcionales a los propósitos jurídicos buscados, p.ej. la viabilidad extrauterina (cfr. Ramón, 2003, pp. 123 y ss.; Peñaranda, 2003, pp. 185 y ss. y Roxin, 2004, p. 1197). Tanto en Alemania -hasta la reforma de 01/04/1998-, cuanto en España -hasta el Código de 1995-, como, en fin, en nuestro país -cfr., Grisolía / Bustos y Politoff, 1971, p. 57; Garrido, 2005, pp. 24 y ss., un antecedente de primera importancia para resolver el problema que nos ocupa viene dado por la regulación del infanticidio (matar (al) "recién nacido", "durante el parto" y "después del parto", respectivamente), delito que no está contemplado en la propuesta, con el consiguiente aumento de la incertidumbre y, también, del espacio para una solución interpretativa que, necesariamente, deberá abarcar los problemas político-criminales involucrados, vid. infra, notas. 37 y 38 . Un argumento político-criminal frecuentemente invocado en este ámbito es que, mientras más se adelante la aplicación de los delitos que protegen la vida y la salud extrauterina, más se intensifica la protección durante el período del parto, lapso de gran indefensión o vulnerabilidad para el producto de la concepción, cfr., Mezger, 1958, pp. 32 y s.; Bacigalupo, 1989, pp. 3 y 6 y ss. y 1994, pp. 13 y s.; Rodríguez, 1990, p. 142; De Figueiredo, 1999, p. 6; Ricciotti / Strano, 1999, p. 1506; Pérez del Valle, 2002, pp. 314 y s.; Olmedo, 2002, pp. 605 y ss.; Alonso, pp. 46 y 63; González, 1996, pp. 115 ys.; Granados, 1999, pp. 241 y ss.; Roxin, op. ult. cit., pp. 1197 y s. y Mendoza, 2005 pp. 1594 y ss. En todo caso, la introducción del delito de lesiones al feto, y del delito de aborto culposo responde a la idea de una protección sin solución de continuidad de la vida y de la salud humana a lo largo de todo el proceso que la misma constituye. Cfr., Lüttger, 1984, p. 75; Farré, 1990, pp. 348 y 353; Gracia, 1997, p. 39; Peñaranda, 2003, pp. 179 y ss.; García, 2000, pp. 48 y ss. y Romeo, 2004a, pp. 251 y ss. La ausencia de una expresa consideración de las lesiones al feto y del aborto imprudente conlleva -como tempranamente lo advirtió Del Río, cit.- una solución de continuidad, un vacío, en la protección aludida, y ello no sólo en los supuestos obvios, y ya por sí solos suficientemente graves -Cfr., infra, nota 10 y bibliografía ahí cit.-, de lesiones al feto y de aborto culposo, sino también (supuesto que el dolo de matar y el de lesionar son autónomos -otra opinión, Novoa, 1945, p. 183 y González, 2000, p. 90) en los casos, no por menos evidentes menos graves, de agresiones fetales que no ocasionan un aborto sino lesiones que subsisten en la vida extrauterina o que provocan la muerte en este último período. Dichas lesiones sólo podrían ser sancionadas como tentativa de aborto si al momento de la acción concurría dolo de aborto -vid., sin embargo, infra, notas 42 y 43 y el texto al que corresponden. En el caso de las lesiones dolosas y de las lesiones o aborto culposo, consumado o tentado, no podría plantearse la solución de la preterintencionalidad para apreciar lesiones u homicidio culposo -así, implícitamente, Schepeler, 1967, pp. 41 y s. y, explícitamente Stampa, 1950 y Cobo del Rosal / Carbonell M. J.C., 1990- por la importancia que se le concede al cambio de status del nasciturus entre el parto y el nacimiento, por un lado y porque, por otro lado falta en estos casos el desvalor de acción del homicidio, doloso o imprudente, por lo que su sanción a ese título importaría responsabilidad objetiva. Además ello importaría: i) que la sanción a título de aborto o de homicidio, en muchos casos, dependería del mero azar; ii) que cualquier conducta dirigida a la provocación del aborto o de lesiones al feto puede devenir en un delito de homicidio y iii) que se sancionarían penalmente las conductas imprudentes de la madre durante la etapa de gestación; no cabe por consiguiente sancionar directamente a título de homicidio y/o de lesiones (vid., sin embargo, de un lado Gracia, 1997, pp. 45 y ss. y Gracia / Escuchuri, 2005; Silva, 2001, pp. 759 y ss.; Huerta, 2001, pp. 1440 y ss. y del otro, Farré, 1999, pp. 349 y ss.; Peñaranda, 2003, pp. 188 y ss. y 234 y ss.; Romeo, 2004a, pp. 267 y s. y Mendoza, 2005, pp. 1605 y ss.; vid. también, infra, notas 36 y 37). La hipótesis en que se coloca Ramón, 2002, pp. 307 y ss. y 318 y ss., es substancialmente distinta de la que aquí nos ocupa; él asume como presupuesto que el dolo inicial del autor es que la muerte se produzca extrauterinamente. Con ello, si bien supera la segunda de las objeciones planteadas, lo hace al costo 
Horvitz y Soto - Consideraciones críticas sobre la regulación del delito de aborto...

iii. Conservación de la punibilidad agravada del tercero que comete aborto a una mujer que consiente en ello, sin fundamento para la agravación ${ }^{10}$;

iv. Ausencia de diferenciación en la punibilidad de las conductas del facultativo en hipótesis de autoría y de participación ${ }^{11}$;

v. Ausencia de tipificación de las lesiones dolosas cometidas en contra del nasciturus, con los consiguientes problemas de delimitación entre el primer y segundo nivel de protección de la vida humana ${ }^{12}$;

de dejar sin resolver las hipótesis verdaderamente relevantes que, antes que una subjetivización del problema, requieren una redefinición paralela del delito de aborto. En este último sentido, vid., infra, notas 36 y 37, texto al que corresponden y bibliografía ahí cit. Vid., también, Kaufmann, 1973, quien descarta que en estos casos haya un acortamiento de la vida (= homicidio), porque sólo hay un nacimiento con expectativa de vida limitada, que dura acorde esa expectativa.

${ }^{10}$ Si cualitativamente la agravación aparece como infundada, luego como discriminación arbitraria, entonces infringe el "principio de proporcionalidad". Cfr. Alexy, 1993, pp. 157 y ss.; 2000 y 2002; Bernal, 2002, pp. 309 y ss.; 2005, esp. pp. 491 y ss., 595 y ss., 613 y ss. y 759 y ss.; y Borowski, 2000. En todo evento la vía del principio de proporcionalidad y el juicio de ponderación no es la única para fundar la inconstitucionalidad. Cfr., p. ej., Häberle, 2003, pp. 183 y ss.; De Domingo, 2000, pp. 216 y ss. y Serna / Taller, 2000. Para una amplia revisión crítica de los criterios alternativos y una defensa de la construcción de Alexy, vid. Bernal, 2005, pp. 253 y ss., con exhaustivas referencias bibliográficas. Vid., también, infra, nota 11.

${ }^{11}$ En los supuestos de aborto consentido la agravación de la pena para el facultativo resulta un verdadero contrasentido, pues dicha intervención disminuye el peligro para la vida y la salud de la madre, por lo que debería importar una atenuación de la responsabilidad penal y no una agravación. Vid., también, infra, n. 39.; Roxin, 2004, p. 1196 y Romeo, 2004 a), pp. 186 y ss.

12 Sobre ello, vid., Kaufmann, 1973; Romeo, 1981, pp. 269 y s. y 279 y ss.; 1994, pp. 400 y ss.; 2004 a, pp.251 y ss.; Lüttger, 1984; Cuerda, 1988 b); Bustos, 1993; Rodríguez, M. J., 1996; Peris, 1995, pp. 160 y ss.; Ramón, 2002; Gracia, 1997; Gracia / Escuchuri, 2005; Huerta, 2001; García, 2000; García, 2004, pp. 143 y ss.; Pérez, 2003, pp. 438 y ss.; Olmedo, 2002; Santana / Senté, 2002; Fernández, 2003; Peñaranda, 2003 y 2005: Roxin, 2004, p. 1198 y Mendoza, 2005. En todo evento, no se postula parificar la protección de la vida y la salud en sus fases prenatal y postnatal; por el contrario, se postula que dicha protección debe ser, global y particularmente, más intensa en la fase postnatal; las penas deben ser significativamente más elevadas, deben sancionarse tanto las conductas dolosas como las imprudentes, sin restricción del círculo de los posibles autores. En lugar de lo anterior, en el ámbito intrauterino, además de penas mucho más bajas, de un lado, es polémico si deben sancionarse los comportamientos culposos -en todo caso sólo de terceros, distintos de la mujer embarazada (cfr. infra, nota 42) y, en caso afirmativo, si sólo debe tipificarse el aborto culposo o si, además deben sancionarse, las lesiones imprudentes al feto; de otro lado, resulta incierto establecer la entidad o gravedad que deben revestir las lesiones al feto para ser merecederas de sanción penal. A este respecto, no debe inducir a error la tesis de la "inversión valorativa" postulada por un sector de la doctrina española (cfr., Cuerda, 1988 a), p. 422; 1988 b, p. 712; Peris, 1995, p. 163; Hernández, 1995, pp. 1999 y s. y, esp., Gracia, 1997, pp. 615 y ss., 644 y ss. y 647 y Gracia / Escuchuri, 2005, pp. 10 y ss). Esta tesis sostiene que en el período fetal, respecto del extrauterino, se produce una inversión de los valores correlativamente asignados a la vida y la salud; así, mientras en el último la vida es inequívocamente más importante que la salud, en la fase intrauterina esta relación se invierte, pasando a ser más importante la salud que la vida. La consecuencia obvia y más importante de este punto de partida es que las penas asignadas a los 
REJ - Revista de Estudios de la Justicia - No 9 - Año 2007

vi. Problemas que plantea la criminalización del delito de aborto imprudente. Alternativas político-criminales más plausibles.

Seguidamente se efectuará el desarrollo separado de cada uno de estos temas.

\section{Ratificación de la opción legislativa y político-criminal iniciada con la dictación de la Ley 18.826 y ausencia total de debate sobre la posible introducción en nuestro ordenamiento jurídico de modelos regulativos comparados que admiten la impunidad del aborto.}

Según es conocido, desde la dictación del Código Sanitario (15/05/1931) y hasta la reforma introducida mediante Ley $\mathrm{N}^{\circ} 18.826$ (15/09/1989) -por consiguiente durante más de 58 años- nuestra legislación, doctrina y jurisprudencia admitió expresamente el denominado aborto terapéutico, establecido primero en el artículo 226 y posteriormente, a partir del D.F.L. 725, de 11/12/1967, en el artículo 119 de dicho Código ${ }^{13}$.

A propósito de la regulación anterior a 1989, existía una importante discusión en torno a la correcta interpretación del artículo 119 del Código Sanitario y sus efectos en la punibilidad del aborto, pues un sector de la doctrina equiparaba el supuesto previsto en él al estado de necesidad olvidando, como recientemente lo ha destacado Bascuñán Rodríguez, que el Código Penal sólo contempla y admite el estado de necesidad agresivo mientras que el aborto terapéutico es un caso paradigmático de estado de necesidad defensivo ${ }^{14}$. Otro sector de la doctrina, por el contrario, equiparaba dicho supuesto al ejercicio legítimo de una profesión, dotándolo así de una mayor amplitud justificante ${ }^{15}$.

delitos de lesiones al feto deberían ser iguales o superiores a las asignadas a las correspondientes figuras de aborto. Como es evidente, la tesis se mueve al interior del segundo nivel de protección de la vida y no altera, ni pretende alterar, la relación del mismo con el primer nivel de protección de la vida, que seguirá resolviéndose en los términos precedentemente apuntados. Para la crítica a la “tesis de la inversión valorativa", vid., Huerta, 2001, pp. 1429 y ss. y; Ramón, 2002, pp. 364 y ss.; Peñaranda, 2003, pp. 166, n. 1, 176 y ss. y 194 y ss. y Mendoza, 2004, pp. 1585 y ss.

${ }^{13}$ Cfr., por todos, con exhaustivas referencias bibliográficas, Bascuñán, 2004 a), pp. 147 y ss.

14 Sobre dicha distinción, vid., Bascuñán, 2004 a), pp. 151 y bibliografía ahí cit. en nota 24 y Bascuñán, 2004 b), pp. 68 y ss. Vid, también, Luzón, 1991 b) y 1996, pp. 617 y ss.; Jescheck / Weigend, 2004, pp. 379 y ss.; Stratenwerth, 2005, pp. 223 y ss., $\mathrm{N}^{\circ}$ s. marg. 71 y ss. y, sintéticamente, Volk, 1993, pp. 83 y ss. Debe tenerse presente, sin embargo, que, como lo destaca Jakobs, 1995, 13 / 22, n. 44 (en alusión crítica al fundamento de la solución de Roxin, quien "asume" que siempre es el nonato el quasi agresor injustus), puede darse también la situación inversa, que sea la madre la que pone en peligro al hijo, sin que le sea imputable esa puesta en peligro, como una acción; como ocurriría, en el ejemplo propuesto por Peñaranda, 2003, p. 214, en que el peligro procede de una estrechez del canal del parto de la madre, a la que entonces podría considerársela como una quasi agressora injusta de su hijo.

15 Cfr., de un lado, Etcheberry, 1965, III, pp. 102 y s.; 1976. III, pp. 229 y s. y, del otro, Grisolía, Bustos y Politoff, 1971, pp. 226 y ss., p. 235. Vid., también, Bascuñán, 2004 a), pp. 151 y ss. 
Horvitz y Soto - Consideraciones críticas sobre la regulación del delito de aborto...

En este contexto, la Ley 18.826 pretendió alterar el estado de cosas preexistente eliminando el aborto terapéutico y estableciendo en su lugar una prohibición casi absoluta de abortar, morigerada sólo por la doctrina del doble efecto proveniente de la teología moral católica ${ }^{16}$.

Conforme a dicha doctrina, y como lo establece el artículo 119 del Código Sanitario, en su actual redacción, "no podrá ejecutarse ninguna acción cuyo fin sea provocar un aborto"; sin embargo, con ello se admite implícitamente, y con eficacia excusante, la producción de dicho resultado como consecuencia no buscada (no querida) de una acción realizada para la consecución de un fin legítimo, supuesto que dicha acción sea proporcionada como medio para alcanzar ese fin. En suma, se prohíbe el aborto con dolo directo pero no el realizado con dolo eventual, cuando el fin directo de la acción es legítimo y constituye la única y exclusiva motivación del comportamiento del autor ${ }^{17}$.

En referencia a esa modificación, desde el ámbito de la dogmática constitucional, Cea Egaña y Mohor Abuauad, entre otros ${ }^{18}$, entienden que, en consonancia con la Constitución, la misma consagra un derecho a la vida del nasciturus $^{19}$, y además lo establece como un derecho absoluto y, consecuentemente,

\footnotetext{
16 Sobre dicha doctrina, vid., Vives, 1957, pp. 235 y ss.; Soto, 1966; Farrell, 1985, pp. 64 y ss.; Ugarte, 1993 y 2006, pp. 64 y ss. y 337 y ss.; Foot, 1994 y Bascuñán, 2004 a), pp. 154 y 159.

17 Ello abre otra posibilidad interpretativa, tan tortuosa y alejada de la historia fidedigna de la disposición y del sentido natural y obvio de la actual redacción del art. 119 como sus alternativas, cual es entender que la misma está referida sólo a aquellas conductas cuyo único y exclusivo y excluyente propósito (justificación) sea provocar el aborto y no, en cambio, a aquellas otras en que, objetiva y subjetivamente, concurre un propósito (justificación) adicional, ética y/o jurídicamente relevantes, que permea el anterior y que, por sobre él, motiva (justifica) la práctica del aborto, que es el caso que se produce en las situaciones abarcadas por las llamadas indicaciones. Para un razonamiento parcialmente análogo, pero referido sólo al aborto terapéutico, en Sanhueza, 1990.

18 Vid. bibliografía nacional cit. supra, nota 4.

19 Que exista un interés constitucional en preservar la vida del "nonato" (“... del que esta por nacer", art. $19 \mathrm{~N}^{\circ} 1$, inc. $2^{\circ} \mathrm{CPR}$ ) es distinto y no implica afirmar que el mismo sea "titular de un derecho a la vida" y, por ende, "persona" en sentido jurídico, titular de derechos subjetivos. Sobre ello, en general, vid., Arroyo, 1980; Lüttger, 1984, pp. 63 y ss.; Farell, 1985, pp. 32 y ss.; Rodríguez, 1987; Ruiz, 1990, pp. 65 y ss.; Hoerster, 1992 b) y c); Jakobs, 2004; Díaz, 2004, Bascuñán, 2004 b), pp. 53 y ss.; Mendoza, 2005, p. 1592 y bibliografía ahí cit.. Para la distinta posición que a este respecto asumen la jurisprudencia constitucional norteamericana y alemana, vid. Bascuñán, 2001; para la doctrina constitucional chilena, críticamente, Bascuñan, 2004 a), pp. 157 y ss.. Más aún, como lo ha destacado la doctrina penal chilena, la exégesis de las disposiciones constitucionales y, adicionalmente, de las disposiciones civiles pertinentes, lleva también a la conclusión de que, normativamente, las calidades de "persona" y de "nonato" son excluyentes (cfr. Art. $1^{\circ}$ inc. 1, CPR., "Las personas "nacen" ...", art. $19 \mathrm{~N}^{\circ} 1$, inc. $1^{\circ}$, "La Constitución asegura a todas las "personas".; luego, personas son los ya nacidos, no el “... que esta por nacer". Cfr., Garrido, 2005, III, p. 24; Politoff / Matus y Ramírez, 2004, p. 22 y, especial, extensa y fundacionalmente, con concordancia de las normas civiles, Etcheberry, 1998, III, pp. 87 y s. y 91 y ss.. En el otro extremo, de una parte, hay autores que niegan que la vida sea el bien jurídico protegido en el aborto -cfr., De Rivacoba, 1984, pp. 132 y ss., quien sostiene que lo protegido es el interés demográfico- y,
} 
afirma una prohibición penal absoluta de realizar abortos. Más aún, se sostiene que el "aborto terapéutico indirecto", único permitido (como consecuencia de la doctrina del doble efecto), debería ser construido como una causal de exculpación y no de justificación. Precisamente esta última es la solución propuesta, desde el ámbito de la dogmática penal, por Rodríguez Collao quien, teniendo a la vista el estado de necesidad agresivo como fundamento del aborto terapéutico, entiende que el nuevo artículo 119 del Código Sanitario excluyó dicha causal de justificación de nuestro ordenamiento jurídico, pues, para los casos excepcionalísimos en los que en la actualidad pudiera darse un conflicto con la vida de la madre, bastaría con reconocer una causal de exculpación ${ }^{20}$.

La doctrina penal dominante, sin embargo, y sólo en el caso del "aborto terapéutico", sostiene, contrariando la historia fidedigna de la ley (y aún su texto), que la actual redacción del artículo 119 del Código Sanitario no sería obstáculo para reconocerlo como causal de atipicidad o de justificación; en síntesis, el artículo 119 del Código Sanitario carecería de toda significación penal ${ }^{21}$.

consecuentemente, niegan que exista un interés en la protección de la vida del "nasciturus" como bien individual; dicha tutela sólo sería pertinente en la medida de los intereses colectivos comprometidos. Por otra parte, en un razonamiento parcialmente paralelo al precedente, con el que difiere radicalmente en la relevancia otorgada a los derechos de la mujer, un sector de la doctrina ha postulado la procedencia del aborto contra la voluntad de la gestante en algunas de las hipótesis que tradicionalmente se conocían como "indicaciones eugenésicas" (hoy, embriopática), lo que supone privilegiar los intereses colectivos, no sólo ya por encima de la vida del "nonato", sino también por encima del derecho a la autodeterminación reproductiva de la mujer (cfr. en este sentido, Díez, 1989 a), pp. 136 y ss., 138 y ss. y esp. 142 y s.. Críticamente, vid., De Figueiredo, 1999, pp. 184 y ss. e infra, notas. 32 y 34 y bibliografía ahí citada).

${ }^{20}$ Como lo ha destacado Bascuñán, 2004 a), pp. 162 y s., esta causal de exculpación, de concurrir, sólo podría producir los efectos propios de su calidad de tal y, por ende, únicamente ampararía la conducta de la mujer embarazada y no, en cambio, a los terceros que pudieran intervenir. Lo anterior, en el caso del aborto terapéutico, que es la hipótesis para la que se la invoca, significa que no aprovecharía a los profesionales de la salud que interrumpan el embarazo, con lo que su relevancia práctica sería en realidad muy menor y no podría en ningún caso suplir la falta de reconocimiento legal de la indicación correspondiente. Sobre el efecto individual de las causas de exclusión de la culpabilidad, vid., Schünemann, 1995, pp. 217 y ss., 223, 227 y s., con expresa referencia a las indicaciones en el aborto y 241 y ss.; Cortés, 1995, pp. 225 y s.; Roxin, 1997, 16 / 71, 1998 a), pp. 85 y ss. y 101 y ss., 1998 b), 205 y ss. y, esp. 252 y ss. y también, con referencia al carácter personal de la atenuación en el autoaborto, Laurenzo, 1997, pp. 286 y s. Da Cunha, 1999, pp. 156 y s. y Feijoo, 2003, pp. 302 y ss. Además, como la conducta de la madre seguiría siendo antijurídica, contra ella cabría legítima defensa o, cuando menos, estado de necesidad defensivo, lo que habilitaría a cualquier tercero a intervenir, justificadamente para impedir la muerte del nasciturus (cfr., Peñaranda, 2003, p. 213).

${ }^{21}$ En efecto, si pese a la historia fidedigna de su establecimiento, se considera que el art. 119 del CS, en su actual redacción, no es obstáculo para la admisión del denominado aborto terapéutico, entonces la reforma de 1989 habría carecido de todo sentido o propósito, pues el "status" normativo antes y después de la reforma sería exactamente el mismo, lo que parece un evidente contrasentido. Las leyes, por un mínimo de deferencia con el legislador, deben interpretarse siempre en el sentido que produzcan algún efecto (viid., Ferreres, 2004, pp. 320 y ss.; Gomes, 2002, pp. 1296 y ss.; también, infra, nota 30). La doctrina dominante (Sanhueza, 1990; Etcheberry, 1998, 
Horvitz y Soto - Consideraciones críticas sobre la regulación del delito de aborto...

El planteamiento más claro en este sentido es obra de Juana Sanhueza Romero, quien considera que en su actual redacción el artículo 119 del Código Sanitario no hace sino reiterar que el aborto está prohibido pero que, al mismo tiempo, las normas penales que sancionan el aborto exigen causarlo "maliciosamente", malicia que, según dejó constancia la comisión redactora, falta en el médico que realiza un "aborto terapéutico"22.

En la misma línea Etcheberry, y siguiéndolo Politoff, Matus y Ramírez, entienden que el artículo 119 del Código Sanitario no excluye el aborto terapéutico de la aplicación del artículo $10 \mathrm{~N}^{\mathrm{o}} 10$ del Código Penal, fundándose para ello en la motivación que sirve de preámbulo a la Ley $\mathrm{N}^{\circ} 18.826$ que, en párrafos que no se identifican, reconocería la existencia de casos excepcionalísimos en que la medicina no estaría en condiciones de controlar el peligro para la vida de la madre, haciéndose aplicables las reglas generales de Código Penal ${ }^{23}$.

En rigor, la referencia al artículo $10 \mathrm{~N}^{\mathrm{o}} 10$ del Código Penal es, como es evidente, al ejercicio legítimo de la profesión de médico y, por su intermedio, a la denominada lex artis, para cuya definición de contenido Politoff, Matus y Ramírez citan el artículo 26 del Código de Ética Médica de 1983, derogado por el nuevo Código de Ética Médica de 14/12/2004 que, sin embargo, no contempla una disposición semejante ${ }^{24}$.

Las construcciones precedentemente referidas, han sido objeto de crítica por Bascuñan Rodríguez, quien ha señalado que:

a) Las mismas no se corresponden a la historia fidedigna del establecimiento de la Ley 18.826.

III, pp. 105 y ss.; Garrido, 2005, III, pp. 118 y s; Politoff / Matus y Ramírez, 2004, pp. 90 ss. y Bullemore / Mackinnon, 2005, p. 39) no se esfuerza mayormente en fundar esta conclusión, que debe resultarles obvia, pero pareciera que dicho fundamento lo halla en la existencia de un conflicto de normas que, excluido el recurso a la jerarquía, lo resuelve por especialidad a favor de la eximente genérica. A nuestro entender, aún cuando esta última no fuera (como es) una meta-regla y supuesto que su contenido previo hubiera estado definido con independencia del art. 119 (en su antigua redacción) y en términos antinómicos con el actual contenido del art. 119 del CS., tanto por especialidad, como por temporalidad debería primar este último al momento de asignar un contenido a la "lex artis", luego a la eximente, en relación al aborto (vid. infra, nota 28). La conclusión anterior sólo se vería alterada si se incorporan a la ecuación criterios de jerarquía y de proporcionalidad, mediante la referencia a los intereses y derechos constitucionales comprometidos (vid. infra. notas 26 y ss. y notas. 31 y 34).

${ }^{22}$ Cfr. Sanhueza, 1990. Sobre esta propuesta interpretativa, cfr. Bascuñan, 2004 a, pp. 164 y 180.

${ }^{23}$ Cfr. Etcheberry, 1998, III, p. 108 y Politoff / Matus y Ramírez, 2004, p. 91, n. 27.

24 Cfr. de un lado, Politoff / Matus y Ramírez, 2004, p. 90; y, del otro, http://www.colegiomedico.cl y Politoff / Matus y Ramírez, 2006, p. 96. En todo evento, el contenido del art. $8^{\circ}$ del Código de Ética Médica de 2004 dista de ser tan conciso como pretenden los autores invocados, pues dicha disposición debe ser puesta en relación con la contenida en el art. $9^{\circ}$ que establece precisamente la doctrina del doble efecto, en total concordancia con la actual redacción del art. 119 del Código Sanitario. 
b) Desconocen que la regla del artículo $10 \mathrm{~N}^{\circ} 10$ del Código Penal no es una norma justificante sino una metaregla, que obliga a identificar las normas que contienen la correspondiente causal de justificación.

c) Olvidan la función que, en cuanto norma configuradora de la lex artis de rango legal, compete al artículo 119 del Código Sanitario ${ }^{25}$.

Este autor postula una solución constitucional fundada en el que denomina "principio de la exigibilidad diferenciada", en cuya virtud aprecia -aunque no sólo en la llamada indicación terapéutica sino también en algunos supuestos de indicación ético-jurídica y en la indicación embriopática- un conflicto de intereses constitucionales que se resuelve en la inexigibilidad para la mujer del deber de tolerar el embarazo, confiriéndole la Constitución una autorización para ejecutar su interrupción. Desde esta perspectiva, el artículo 119 del Código Sanitario, en la redacción que le dio la Ley 18.826, sería inconstitucional.

Bascuñán sostiene que el artículo 119 del Código Sanitario resulta inconstitucional en cuanto niega el conflicto de intereses constitucionales que se produce con ocasión del embarazo, al que es consustancial un cierto grado y margen de afectación de intereses personalísimos de la mujer, fundamentalmente, su autodeterminación reproductiva. La exigibilidad del deber de tolerar el embarazo implica la exigibilidad de la afectación de esos intereses en ese margen y grado. Cualquier situación en la que el embarazo origine para la mujer el sacrificio de sus intereses por encima del margen y grado determinados por la medida anterior pone en cuestión la exigibilidad del deber de tolerarlo. Por ello, la pretensión de la Ley 18.826 de establecer una exigibilidad absoluta del deber de tolerar el embarazo sería entonces inconstitucional ${ }^{26}$.

Descartando que en nuestro país esté establecido un sistema de control difuso de constitucionalidad, Bascuñán sugiere dos vías para hacer valer la inexigibilidad constitucional antes referida ${ }^{27}$ :

a) de una parte y como es obvio está el recurso de inaplicabilidad por inconstitucionalidad, en relación al cual advierte, con razón, que no basta con la invocación del artículo $10 \mathrm{~N}^{\mathrm{o}} 10$ del Código Penal y que, sin declaración de inaplicabilidad del artículo 119 del Código Sanitario, no es

\footnotetext{
${ }^{25}$ Cfr. Bascuñan, 2004 a, pp. 165 y ss.. Vid. también, supra, nota 21 e infra, nota 28.

${ }^{26}$ Bascuñan, 2004 a, pp. 167 y ss.

27 Bascuñan, 2004 a, p. 180. La sola existencia y regulación del recurso de inaplicabilidad como una facultad exclusiva del Tribunal Constitucional ratifica que en nuestro país rige un régimen centralizado de control de constitucionalidad. Vid., sin embargo, infra, nota 29 y bibliografía ahí citada. Sintéticamente, sobre la opción por un control centralizado o descentralizado y sus consecuencias, vid., Ferreres, 2004, pp. 305 y ss.
} 
Horvitz y Soto - Consideraciones críticas sobre la regulación del delito de aborto...

posible construir una causa de justificación supralegal o por referencia a la ética médica ${ }^{28}$;

b) de otro lado sugiere una interpretación conforme a la Constitución, que reconduzca la aplicación del artículo 119 del Código Sanitario sólo y únicamente al ámbito del derecho sanitario y no, por oposición, al derecho penal, en relación al cual la situación sería la misma que existía con anterioridad a $1931^{29} /{ }^{30}$.

En definitiva y a este respecto, la PACP, con su continuismo, mantiene las incertezas y dificultades interpretativas planteadas por la doctrina al amparo de la regulación actualmente vigente, sin dar solución a ninguno de ellos. Peor aún, en su pretensión inmovilista, la PACP se pronuncia, implícita pero inequívocamente, a favor de la constitucionalidad de artículo 119 del Código Sanitario, en su actual redacción, ratificando con ello la tendencia de la política criminal sobre el aborto iniciada en $1989^{31}$.

\footnotetext{
${ }^{28}$ En efecto, el art. 119 del CS. constituye un antecedente insoslayable al momento de precisar el contenido de la lex artis en el ámbito que nos ocupa; para esos efectos, además y como ya se indicó -supra, nota 21-, dicho antecedente, tanto por jerarquía, como por especialidad, prima sobre las normas reglamentarias o puramente éticas de signo contrario que, de existir, pudieran oponérsele. Vid., supra, notas 21 y 24 e infra, nota 31.

${ }^{29}$ Sobre la interpretación conforme a la Constitución, vid., Jiménez, 1995; Gascón, 2002; Gomes, 2002, pp. 1294 y ss.; Ferreres, 2004, pp. 314 y ss. y López, 2004, con abundantes referencias bibliográficas y situación en diversos países europeos. Para el efecto irradiante, Carrió, 1959; Bockenforde, 1993, pp. 110 y ss.; Ferreres, 2001; Jana, 2001. Para las dificultades que entraña deslindar la interpretación conforme a la Constitución del control de constitucionalidad puro y duro y, por consiguiente, para distinguir el control centralizado del descentralizado, Bascuñán, 2004 a, p. 108 , nota 88 .

${ }^{30}$ En definitiva, Bascuñán postula restringir interpretativamente la aplicación del art. 119 del Código Sanitario al ámbito de las infracciones administrativas contempladas en el Derecho Sanitario (cit., 2004 a, pp. 180 y s.) Dicha solución, sin embargo, parece contradictoria con la conclusión a que, paralelamente, llega en relación a la constitucionalidad del art. 119 del CS., en las situaciones de conflicto que constituyen el supuesto de hecho de las indicaciones terapéutica, éticosocial y en algunos casos de la indicación embriopática. Si la norma, en esas situaciones de conflicto, es inconstitucional, también, y por las mismas razones invocadas, debería serlo para el derecho administrativo sancionador, que sólo se diferencia cuantitativamente del derecho penal. La referida diferencia cuantitativa, sin embargo, podría invocarse para sostener que en el ámbito administrativo penal el conflicto se presenta en términos menos intensos que en el criminal penal; por lo que no necesariamente debiera resolverse en la inconstitucionalidad. En todo evento, vid., de un lado, supra, nota 21 y del otro, supra, nota 1; también, Laurenzo y referencias a la jurisprudencia constitucional alemana ahí citada y, más en general, Günther, 1995; Luzón, 1995 y críticamente respecto de Günther, Diez, 1985 y Cortés, 1995, pp. 267 y ss.

31 Vid. supra, nota 6. En cualquier caso, como lo destaca Farrell, 1985, pp. 97, la forma óptima de solucionar el conflicto a que se alude a continuación en el texto -y en la nota siguiente-, es a través de un pronunciamiento expreso del legislador y no, en cambio, dejándolo entregado a soluciones jurisprudenciales, más o menos felices, más o menos discutibles; dichas soluciones jurisprudenciales siempre adolecerán de un sensible déficit de legitimidad frente a la solución legislativa. Vid., también, supra, nota 1 e infra, nota 34. En cualquier caso, si lo que se quería era producir la situación aludida supra, nota 21 -amplia procedencia de la indicación terapéutica- entonces la
} 
En suma, la mayor crítica que puede formulársele a Anteproyecto radica en haber desaprovechado la oportunidad de someter a discusión la introducción, en nuestra legislación, de un sistema de indicaciones o de un sistema de plazos que reconociera los derechos de la mujer comprometidos y afectados con el embarazo ${ }^{32}$.

Por nuestra parte somos partidarios del aborto impune durante los tres primeros meses del embarazo, eventualmente con consejo forzoso, como en el caso alemán ${ }^{33}$. Tal propuesta, como parece evidente, jamás fue admitida como posible por su radicalidad liberal. Sin embargo, no puede entenderse que se haya desechado totalmente la posibilidad de introducir el sistema (más conservador) de las indicaciones, como el vigente en España. Esta omisión parece aún más grave si se considera que desde la perspectiva constitucional es posible sostener el estatus de derecho subjetivo público de los derechos de la mujer, el que es restringido y afectado por el hecho del embarazo, mientras que no aparece tan claro ni evidente dicho estatus para la vida del nasciturus ${ }^{34}$, circunstancia que debió haber conducido

solución más directa y, al parecer, escasamente conflictiva, habría sido proponer derechamente la derogación del actual art. 119 del CS. Con ello desaparecerían los obstáculos más fuertes que pueden oponerse a la solución propuesta por la doctrina dominante (supra, notas 21 y 28), dando lugar a un cuadro normativo substancialmente idéntico al que existía antes de la dictación del Código Sanitario en 1931, en cuyo contexto no existía una oposición fundada a la admisibilidad del aborto terapéutico. Para esto último, cfr., Bórquez, 1922, pp. 13 y ss., Bascuñán, 2004 a, pp. 144 y ss. y bibliografía ahí citada.

32 La PACP, al mantener inmodificado el cuadro normativo creado por la reforma de 1989 (explícitamente, Bustos, 1993; Ugarte, 1993; Casas, 1993 y bibliografía citada, supra, nota 4) desconoce o reduce a la intrascendencia los derechos fundamentales de la mujer, de innegable rango constitucional, que se ven severamente restringidos con ocasión del embarazo, asumiendo e imponiendo en su lugar, como único interés relevante, la preservación de la vida del nasciturus. Sobre dicho conflicto, vid. Thomson, 1997 y 2001; Farrell, 1985, pp. 13 y ss.; Bajo, 1986, pp. 113 y ss. y 1991, pp. 124 y ss.; Landrove, 1987, pp. 217 y ss.; Rodríguez 1990, pp. 137 y s.; Laurenzo, 1990, pp. 126 y ss.; Carbonell M., 1991, pp. 660 y ss.; Ramón, 2002, pp. 345 y ss.; Peñaranda, 2003, pp. 207 y ss.; Feijoo, 2003; Roxin, 2004, pp. 1194 y ss. y Bascuñán, 2004 a y b. Vid., también, supra notas 3 y 19 e infra, nota 34 .

33 Según Roxin, este modelo, al que denomina "de asesoramiento", corresponde a una solución de compromiso entre el modelo de las indicaciones y del plazo. Cfr. Roxin, 2004, pp. 1995 y s.; también, infra, nota 35.; De Figueiredo, 1999, pp. 175 y ss..y Eser, 2001, p. 278, con expresa referencia crítica a la tensión interna de este "modelo de asesoramiento", pp. 278 y s.

34 Vid. supra, notas. 19 y 32. La concurrencia de dicho conflicto y la afectación de derechos fundamentales de la mujer -en la hipótesis en referencia, vida y salud- es particularmente evidente y por ello innegable, en los supuestos de hecho abarcados por la denominada "indicación terapéutica". Así, por ejemplo, la Corte Constitucional italiana, en su momento, declaró inconstitucional el antiguo art. 546 del Código Penal italiano, en cuanto sancionaba a la mujer que abortaba amparada en la indicación terapéutica (cfr. Longo/Ghedini, 2000, p. 264 y Rodríguez, 1980, p. 902). El Tribunal Constitucional español, por su parte, ha declarado, en relación a la indicación embriopática, que en tales supuestos “(...) el recurso a la sanción penal entrañaría la imposición de una conducta que excede lo que normalmente es exigible a la madre" (cit. por Landrove, 1987 , p. 228). Pero la concurrencia del conflicto también es innegable en los casos 
Horvitz y Soto - Consideraciones críticas sobre la regulación del delito de aborto...

al reconocimiento de un conflicto de intereses constitucionalmente relevante en el caso de la mujer que comete autoaborto o consiente que otro se lo practique por las razones que fundamentan la indicación terapéutica, ética, embriopática o incluso, la social (en un país donde esta última tiene especial relevancia) ${ }^{35}$.

comprendidos por la indicación ético-social, en los que el embarazo -inequívocamente no deseadoes producto de una violación o de otro delito de significación sexual cometido en perjuicio de la mujer. La falta de reconocimiento de dicha indicación significa imponer a la mujer el deber de tolerar dicho embarazo hasta su término, con la consecuente restricción -arbitraria- de su autonomía personal. Lo mismo sucede en las hipótesis incluidas en la indicación embriopática (piénsese, por ejemplo, en el embarazo de un feto que se sabe dotado de escasa o nula viabilidad extrauterina). En este contexto, la solución interpretativa propuesta por la doctrina penal dominante (cfr. supra, nota 21), sólo resolvería el conflicto en los supuestos, infrecuentes en la práctica, comprendidos en las hipótesis de "aborto terapéutico" (vid., sin embargo, infra, nota 35, in fine) y, dentro de ellos, indiscutidamente, sólo en aquéllos en que está en peligro la vida de la madre (cfr. supra, nota 15); por el contrario, dicha solución interpretativa no alcanza los conflictos, verdaderamente relevantes, que corresponden a la indicación ético-social, embriopática, ni, mucho menos, a aquellos que subyacen a la indicación económico-social (en el mismo sentido y críticamente, Bascuñán, 2004 a, pp. 143 y s.) En cualquier caso, y en el marco de una propuesta legislativa elaborada acorde criterios técnicos (vid., supra, notas 1, 3, 5 y 6) por especialistas en un momento muy anterior al propiamente legislativo y sus exigencias (vid., supra, nota 2), habría sido mucho más coherente con la calidad de los participantes, proponer al menos una solución de indicaciones, propendiendo al debate en un ámbito en el que éste ha estado por completo ausente; y posibilitando, eventualmente, en el terreno estratégico de las ventajas contingentes que, aunque la propuesta se perdiera en el parlamento, se obtuviera, a lo menos, la derogación del art. 119 del CS (vid., supra, nota 31). Respecto a los intereses y derechos comprometidos en las situaciones de conflicto abarcadas por las llamadas indicaciones, cabe advertir que algún sector de la doctrina, confundido quizás por su frecuente denominación como "indicación eugenésica", ha propuesto un fundamento propiamente eugenésico para la "indicación embriopática” (cfr. Díez, 1989 a, pp. 136 y ss., 138 y 141 y s.), entendiendo que en estos casos están comprometidos, de un lado, la salud de la futura persona y, del otro, intereses sociales de carácter supraindividual, vinculados al interés colectivo en el nacimiento de personas sanas (cfr., en este sentido, Díez, 1989 a, y 1989 d, pp. 707 y ss.; Rodríguez M., M. J., 1996, p. 1079 y, sólo en ese texto, Carbonell M./González, 1996, p. 813). La doctrina ampliamente dominante rechaza este punto de vista y remite el fundamento de la indicación a un conflicto entre la autonomía o autodeterminación reproductiva de la mujer y la vida, severamente restringida a futuro del feto (Cerezo, 1982; Lüttger, 1984, pp. 76 y s.; Arroyo, 1986; Bajo, 1991, pp. 125 y s.; Carbonell M., 1991, pp. 669 y ss.; Laurenzo, 1990, pp. 135 y ss.; González, 1997, p. 131; 2000, p. 87; Carbonell / González, 1999, p. 116; De Figueiredo, 1999, pp. 184 y ss.; Muñoz, 2002, p. 97; Ramón, 2002, p. 358 y ss.; Peñaranda, 2002, pp. 195 y ss.; Feijóo, 2003, pp. 318 y ss.; Romeo, 1996, pp. 281 y ss. y 2004 a, pp. 197 y ss. y Bascuñán, 2004 a, p. 177).

${ }^{35} \mathrm{La}$ denominada "indicación económico-social" o "indicación social" puede ser recepcionada en la legislación con muy distinta amplitud, dependiendo del grado o intensidad de penuria económica que se exija para que entre a operar. Según sea esa amplitud, la solución que se establezca estará más cerca del sistema del plazo (concepción amplia de la indicación económico-social) o, en su lugar, del sistema de indicaciones propiamente tal (concepción restringida, con gran número de requisitos para la indicación). De otro lado, debe tenerse presente también que la indicación económico-social, según las características de la embarazada y sus circunstancias, puede revertir en la indicación terapéutica, en la medida en que se vea afectada la salud, normalmente psicológica o psiquiátrica, de la madre (cfr., Bascuñán, 2004 a, p. 178 y De Figueiredo, 1999, pp. 182 y s.). Ello también puede ocurrir con la indicación embriopática, en casos en los que concurre su presupuesto, pero falta alguno de sus requisitos (vgr. se cumplió el plazo legal), en tanto ella puede constituir un 


\section{Diferencias en la determinación de la actividad típica que pueden generar relevantes problemas interpretativos, y que dicen relación con lo protegido con el delito de aborto, y el ámbito al que se extiende la protección penal de la vida a este título de incriminación.}

La propuesta no innova respecto del Código Penal de 1875 y mantiene la actividad típica centrada en el concepto de aborto con las consiguientes críticas ${ }^{36}$.

Conforme al Diccionario de la Real Academia de la Lengua española $\left(21^{\circ}\right.$ ed., Madrid, 1992), aborto es "acción de abortar" y "abortar" es, entre otras acepciones no pertinentes, "interrumpir la hembra, de forma natural o provocada, el desarrollo del feto durante el embarazo". La reforma era la oportunidad de mejorar técnicamente los tipos, especificar la conducta prohibida y delimitar el ámbito de protección de la norma. En efecto, si la conducta debe realizarse durante el embarazo, ¿cuándo finaliza éste y comienza la aplicación de los tipos penales referidos a la protección penal de la vida humana independiente? ¿Hay aborto cuando se mata al feto durante el proceso del parto natural, es decir, sin "interrupción del desarrollo del feto"? Si el feto es muerto antes de que se produzca la completa separación del nasciturus del cuerpo de la madre, esto es, antes del nacimiento, ¿'es aborto, homicidio o infanticidio? ¿Qué ocurre si el feto es objeto de una acción matadora mientras se halla en el vientre materno, pero nace vivo y sólo muere tiempo después como consecuencia de las graves lesiones sufridas?

Para responder a todas estas interrogantes, un sector de la doctrina española, que utiliza la misma técnica de la PACP, ha sostenido que el aborto es "toda interrupción provocada del proceso fisiológico de gestación que ocasiona la muerte del producto de la concepción" ${ }^{37}$, en una significación que claramente no

gravamen para la salud psiquiátrica o psicológica de la madre (cfr., en relación a la hipótesis del embrión contagiado intrauterinamente con SIDA, Romeo, 2004 d., p. 229).

${ }^{36}$ Los tipos penales que se proponen giran en torno a la actividad de cometer, consentir o cooperar a un aborto. La diferencia sustancial es que el Código Penal de 1875 utiliza la fórmula "causar" un aborto; por consiguiente, la innovación consistiría, fundamentalmente, en la erradicación de cualquier interpretación que admita la responsabilidad objetiva en estos delitos; discusión que la doctrina mayoritaria considera, en gran medida, superada.

${ }_{37}$ González Rus, 1997, p. 116; el mismo, 1993, p. 10; 2000 p. 78 y 2004, p. 124. En igual sentido, Peñaranda, 2003, p. 186, quien señala: “... el delito de aborto... se consuma... en general, por la causación de la muerte, antes, durante o después del parto, siempre que ella sea objetivamente imputable a una conducta que incida negativamente sobre el objeto material de este delito (el embrión o el feto) durante su gestación" (los paréntesis en el original). Luego, lo determinante para la calificación de aborto no es el momento de la producción del resultado y la calidad -de "nonato" o "neonato"- que a ese momento pudiera tener el objeto material de la conducta, sino la calidad que este último tenga al momento en que la conducta comienza a tener efectos (a incidir) sobre él: si a ese momento el objeto material es un embrión o feto, entonces la conducta será constitutiva de aborto, con total independencia de que el resultado muerte se produzca cuando el producto de la concepción ya es persona (vid., supra, nota 7 y bibliografía ahí citada). El tratamiento de las 
Horvitz y Soto - Consideraciones críticas sobre la regulación del delito de aborto...

corresponde a la etimológica. Con ello, se quiere destacar que se castiga penalmente la acción de matar al embrión o feto; que la acción típica está constituida por interrumpir un proceso fisiológico -no patológico- de gestación, y que resulta indiferente que la destrucción se produzca dentro o fuera del vientre materno. Estos problemas interpretativos, que se han dado en la práctica jurisprudencial chilena, pudieron haberse subsanado con una descripción típica más prolija y conforme al bien jurídico protegido.

En efecto, tradicionalmente la doctrina nacional dominante ha designado el momento del nacimiento (que, a su vez identifica con el parto) como aquél en que se produce la cesura entre los tipos que protegen la vida dependiente y aquéllos que protegen la vida y la salud extrauterina. Paralelamente, el nacimiento se vincula a la calidad de individuo, entendida como autonomía de vida y, por tanto, a la existencia de las funciones circulatoria y respiratoria independientes de la madre ${ }^{38}$. En la propuesta de PACP desaparece el infanticidio, circunstancia que, a nuestro juicio, aumenta la incertidumbre respecto de la calificación jurídica de los atentados cometidos "durante el parto" y, en particular, respecto de las lesiones, dolosas o culposas, cometidas en perjuicio del nasciturus durante dicho proceso. La doctrina española dominante, antes -con referencia a la regulación del infanticidioy después de 1995 requiere la finalización del parto para castigar tales hechos por

denominadas "actuaciones prenatales" con consecuencias lesivas postnatales no es, sin embargo y según ya se indico, pacífico. Frente a la opinión dominante, que atiende a la cualidad del objeto material al momento en que la acción comienza a incidir sobre él, un sector de la doctrina entiende que hay que atenerse a la cualidad del objeto material al momento de la producción del resultado (cfr., por todos, Cobo del R./Carbonell M. J.C., 1988, p. 488), mientras que otro sector doctrinario, a lo menos respecto de las actuaciones prenatales que producen la muerte postnatal, entienden que debe apreciarse un concurso ideal entre tentativa de aborto y homicidio imprudente, suponiendo naturalmente, el dolo de dar muerte al producto de la concepción (vid., en este sentido, Gracia, 1997, p. 45 y Silva Sánchez, 2001, pp. 759 y ss., esp. 765 y ss.). Según ya se señaló antes (vid. supra nota 7 y siguiendo a Armin Kaufmann, 1973, p. 16), si se extienden los preceptos sobre homicidio y lesiones imprudentes a las actuaciones antenatales con efectos postnatales, "se llegaría, respecto de las exigencias de cuidado, exactamente al mismo resultado que se obtendría si se declarara la punibilidad del aborto culposo", (destacados en el original), incluso del cometido por la propia mujer embarazada. Así lo postula explícitamente Montano (1997, p. 414). La consecuencia obvia del criterio aquí mantenido es, según ya se apuntó, que las hipótesis de aborto culposo y de lesiones dolosas o culposas al embrión o al feto son atípicas. Nuestra jurisprudencia, incidentalmente, se ha pronunciado en el mismo sentido. Así, y dejando de lado la inadecuada caracterización que ha hecho del delito de aborto, el conocido fallo contra Rogelia Maldonado Maldonado, puede interpretarse como una confirmación que las lesiones al feto son atípicas (vid. contra Rogelia Maldonado Maldonado. C. de Valparaíso, 28 de octubre de 1935. Gaceta de los Tribunales, 1935, II, Sentencia $\mathrm{N}^{\circ}$ 123). Más claramente, y en referencia a una acción prenatal imprudente con resultado de muerte postnatal, en la sentencia contra Navarrete Paiva se afirma la inexistencia de un aborto culposo, por no estar dicha conducta tipificada como delito en la ley, y la inexistencia de un homicidio imprudente, por no existir el objeto material de este último delito “(...) al ocurrir la conducta enjuiciada” (cfr. contra Navarrete Paiva, RDJ., T. XXXIV, (1987) $2^{\circ}$ parte, sec. $4^{\circ}$ ).

${ }^{38}$ Cfr. Etcheberry, 1998, pp. 33 y ss.; Garrido, 2005, pp. 24 y ss. y Politoff, Matus y Ramírez, pp. 22 y s.. Más matizadamente, con expresa referencia al infanticidio, Bustos, Grisolía y Politoff, 1971, pp. 57 y s. y Bullemore/ Mackinnon, 2005, p. 16. 
cualquier título de incriminación correspondiente al primer nivel de protección de la vida humana ${ }^{39}$. El sector minoritario, no obstante, lo vincula al comienzo de la expulsión del claustro materno y/o a la autonomía de vida ${ }^{40}$. En la doctrina alemana, tradicionalmente teniendo a la vista la regulación del infanticidio, pero también después de 1998, la opinión dominante se muestra favorable a considerar para estos efectos el comienzo del parto ${ }^{41}$. Por nuestra parte, tanto en relación al Código Penal, como en referencia al Anteproyecto, entendemos que lo coherente con la distinta protección penal de la vida intra y extra uterina, es situar dicha cesura en el momento del término del parto, pues, como señala Peñaranda, “(...) resulta crucial para diferenciar el campo de aplicación respectivo de las reglas de tratamiento de colisiones de intereses que operan (deberían operar) específicamente en el delito de aborto... y las reglas generales que han de entrar en juego cuando los conflictos se dan entre personas que cuentan con una existencia independiente; sin olvidar que la precisión de ese límite viene igualmente requerida para establecer con seguridad el ámbito en que no se exige de la mujer que configure su modo de vida en atención a la que se gesta en su interior, lo que se traduce en la impunidad para ella del aborto imprudente" ${ }^{\text {"42 }}$.

Por otro lado, parece indispensable no sólo especificar la conducta típica del aborto para delimitarla claramente de aquélla que sirve de base a la protección del primer nivel de protección de la vida humana (la vida humana independiente), sino también para definir el hito a partir del cual comienza la protección penal de la vida humana dependiente; esto es, desde qué momento es aplicable este delito, antes del cual la conducta resta impune. Esta es la solución alemana, que en el parágrafo 218 StGB establece expresamente que las conductas típicas cuyas consecuencias se produzcan antes de la implantación del embrión o huevo fecundado en el útero no constituyen aborto en el sentido de la ley penal. Se señaló en el Foro que no era políticamente viable restringir expresamente el ámbito de aplicación del aborto, no obstante los innumerables argumentos que esgrime la doctrina para hacerlo así. En efecto, la PACP elude un pronunciamiento relativo al umbral mínimo del segundo nivel de protección de la vida, que en el derecho y la

\footnotetext{
${ }^{39}$ Cfr. Del Rosal, Cobo, Rodríguez M., 1962, pp. 132 y ss.; Díez, 1989 b, pp. 59 y ss.; Farré, 1990, pp. 341 y ss.; Romeo, 1981, p. 279, 1994, pp. 157 y s., 2004, p. 13 y ss.; Queralt, 1996, pp. 6 y ss.; Gracia, 1997, pp. 39 y ss.; Ramos, 2002, p. 93 y Huerta, 2001, p. 1430). Un criterio cercano es el de Bustos, 1991, p. 18.

${ }^{40}$ Así, González Rus, 1996, pp. 15 y s. y 20 y s.; Huerta, 1977, p. 53; Bacigalupo, 1989, pp. 3 y 6 y ss.; Pérez del Valle, 2002, pp. 314 y s.; Olmedo, 2002, pp. 605 y ss.; Santana-Senté, 2002, p. 643 y Alonso de Escamilla, 2001, pp. 46 y 63.

41 Vid., Peñaranda, 2003, pp. 170 y ss., Roxin, 2004, pp. 1197 y s.

42 Peñaranda, 2003, p. 218, los paréntesis son nuestros. En nuestro ordenamiento, supuesta la declaración de inconstitucionalidad del art. 119 del Código Sanitario en relación al aborto terapéutico, las reglas específicas son las relativas al aborto terapéutico y al régimen privilegiado del autoaborto y del aborto consentido. Lo relevante, en todo caso, es que la solución sea coherente con lo que es el núcleo del problema jurídico del aborto, cual es el conflicto que se da o puede darse entre el interés en la vida del nasciturus y los derechos de la mujer severamente conculcados por el embarazo.
} 
Horvitz y Soto - Consideraciones críticas sobre la regulación del delito de aborto...

doctrina comparadas se sitúa con buenas razones en el momento de la anidación del embrión en el útero materno, esto es, no se brinda protección penal en el lapso que media entre la concepción y la anidación ${ }^{43}$.

Como sabemos, un sector de la doctrina se inclina por entender que la protección penal comienza con la concepción, pues desde ese momento hay una individualidad genética, esto es, hay un nuevo código genético, singular e irrepetible que debe ser objeto de protección penal, lo que ha sido ratificado, $a$ fortiori, por las decisiones de la Corte Suprema en relación a la píldora contraceptiva post-coital. No obstante, nos parece que, más allá de la ardua discusión sobre el momento en que comienza la vida humana, existe un poderoso argumento de texto a favor de la tesis exegética minoritaria, consistente en que los tipos penales de aborto en el Código Penal vigente y, por consiguiente, también los propuestos en la PACP, están construidos sobre la base de la existencia de un embarazo, esto es, presuponen dicho fenómeno; y pareciera que, como mínimo, la existencia de un embarazo requiere la anidación, en tanto relación simbiótica que confiere estabilidad entre el cuerpo de la mujer y el del nasciturus.

Dicho argumento de texto, negado por la opinión dominante, y otros de carácter técnico, científico-naturales y de político-criminal que pueden citarse en el mismo sentido no serían necesarios si el Código Penal estableciera el momento preciso en que comienza la protección penal de la vida humana, con las consecuencias que ello tendría para la configuración del tercer nivel de protección de la vida: la protección de la vida extrauterina.

La cuestión, como se sabe, no es trivial. Se trata de hacer explícito el problema de la eventual intervención penal de cualquier práctica que interrumpa el embarazo y determine la muerte o lesiones del nasciturus desde la fecundación hasta

\footnotetext{
${ }^{43}$ En Italia, donde la legislación tampoco precisa dicho extremo, el punto es hasta hoy objeto de disputas. Cfr., Mantovani, 1991, p. 414 y s.; 1993, pp. 110 y s.; Romano, 1989, pp, 69 y s.; Moccia, 1990, pp. 871 y ss.; Eusebi, 1988, p. 1066; 2001, pp. 43 y ss., con expresa referencia al carácter abortivo de la píldora del día después, pp. 47 y s.; Flamigi, 2001, pp. 103 y ss.. En el ámbito de la dogmática española, mayoritariamente favorable al criterio de la anidación, vid. García, 1981, p. 93; Rodríguez, 1990, p. 142; Barbero, 1991, pp. 170 y ss., Bajo, 1991, p. 116; Suárez G., 1997, p. 449; Lascurain, 1997, p. 421; Laurenzo, 1997, p. 292; Ramón, p. 427; Huerta, 2001, p. 1431; Olmedo, 2002, p. 606 y Mendoza, 2005, p. 1591. En la doctrina penal chilena, parece ser opinión dominante el criterio de la concepción. Cfr., en ese sentido, Etcheberry, 1976, p. 66; Labatut, 1983, p. 127; Schepeler, 1967, p. 37 y Novoa, 1969, pp. 63, 66 t s. y 68. En cualquier caso, como lo reconoce la doctrina comparada ampliamente dominante y lo postulan en la chilena Garrido y Politoff / Matus y Ramirez, existen buenas razones, bio-médicas, jurídicas y político-criminales para inclinarse por el criterio de la anidación. Sobre ello, por todos, convincentemente, vid., Bascuñán, 2004 b, pp. 49 y ss. y esp. 76 y ss. En cualquier caso, y contra lo que parece afirmar Ugarte (2006, pp. 225 y ss.), no se trata de establecer desde cuándo existe vida, sino desde qué momento es posible y conveniente su protección penal. Una imprecisión legislativa a ese respecto puede lesionar el principio de legalidad. Sobre el "principio de determinación" o "principio de taxatividad", vid., por muchos, Moccia, 2001, Ferreres, 2002 y bibliografía ahí citada.
} 
la anidación, incluidos algunos métodos habitualmente utilizados de contracepción, que evitan la anidación del óvulo fecundado, como los dispositivos intrauterinos, y, eventualmente, según algunos y en ciertos casos, la denominada "píldora del día después".

No es posible evitar la discusión sobre temas conflictivos porque se trata, en definitiva, de determinar qué es lo que se quiere proteger a través del instrumento penal y si se encuentra justificado el merecimiento y la necesidad de pena, más aun cuando no existen leyes ni reglamentos que regulen esta materia.

III. Conservación de la punibilidad agravada del tercero que comete aborto a una mujer que consiente en ello, sin fundamento para la agravación.

La PACP mantiene la sistemática del Código Penal de 1875 y castiga con mayor pena al tercero que comete un aborto si la mujer consiente (art. 92.3 $)$ que a la mujer que causa su propio aborto o consiente que otra persona se lo cometa (art. 93). Sin embargo, la mayor pena del tercero que comete aborto con el consentimiento de la mujer no tiene justificación alguna desde la perspectiva de los bienes jurídicos en juego o intereses en conflicto. En efecto, es posible fundar la mayor punibilidad del tercero, en los casos de los $\mathrm{N}^{\circ} 1$ y 2 del art. 92 del CP, porque, además, de atentarse contra la vida del nasciturus se está afectando el derecho a la autodeterminación reproductiva de la mujer, lo que se denota a través de los medios utilizados para realizar la conducta (con violencia o intimidación, mediante engaño o sin su consentimiento).

Por otro lado, el menor reproche jurídico-penal para la mujer que comete su aborto o consiente que otro se lo cometa radica en que sólo se está afectando la vida del nasciturus y no su derecho a la autodeterminación reproductiva. Si ello es así, ¿por qué se castiga agravadamente la conducta del tercero que comete aborto con el consentimiento de la mujer? Una interpretación posible hubiera sido sostener que el art. $92 \mathrm{~N}^{\circ} 3$ se refiere al caso de la mujer cuyo consentimiento se encuentra viciado por engaño; sin embargo, dicha hipótesis ya está en el art. $92 \mathrm{~N}^{\circ}$ 2 CP. Por lo tanto no vemos justificación alguna para el tratamiento punitivo más agravado del tercero en el caso del art. $92 \mathrm{~N}^{\circ} 3 \mathrm{CP}$.

\section{Ausencia de diferenciación en la punibilidad de las conductas del facultativo y en hipótesis de autoría y de participación.}

Del mismo modo constituye un exceso la mantención del tipo del aborto del facultativo, modificando sólo la modalidad de agravación de la pena (inhabilitación especial para el ejercicio de su profesión en su grado máximo) y 
Horvitz y Soto - Consideraciones críticas sobre la regulación del delito de aborto...

manteniendo en lo demás la doble agravación (por cooperar al aborto) que sanciona al partícipe como autor ${ }^{44}$.

Si bien desde una perspectiva preponderantemente subjetiva (y es dudoso que sea la que inspira en general a la PACP) puede sostenerse, como se ha sostenido en el derecho comparado ${ }^{45}$, que hay un mayor desvalor de acción en la conducta del facultativo por la infracción de deberes jurídicos específicos, en el plano objetivo y en punto al aborto con el consentimiento de la mujer, la intervención del facultativo disminuye significativamente el riesgo para la vida y la salud de la mujer, por lo que resulta un contrasentido la mantención de la hipótesis agravada.

La única y discutible solución interpretativa a tal contrasentido es entender que el abuso del oficio concurre siempre que el facultativo causa el aborto sin el consentimiento de la mujer; luego, sólo cuando abusa de su oficio y no, en cambio, cuando interviene con el consentimiento de aquélla.

En definitiva, no hallamos justificación político-criminal alguna para haber mantenido inalterada esta regulación sin haber optado resueltamente por un distinto tratamiento punitivo respecto del facultativo que comete un aborto consentido por la mujer de aquél en que no media el consentimiento de la misma, ni tampoco que se haya mantenido la misma pena para formas de participación materialmente diferenciadas ("cometa un aborto o coopere a él")

\section{Ausencia de tipificación de las lesiones dolosas cometidas en contra del nasciturus, con los consiguientes problemas de delimitación entre el primer y segundo nivel de protección de la vida humana.}

Si bien concordamos en que no se sancione el aborto imprudente ni las lesiones imprudentes al feto, imputables a la propia mujer embarazada o realizadas con su consentimiento, llama la atención que la PACP, en el contexto de un tratamiento punitivo globalmente más riguroso, no haya aprovechado la oportunidad para tipificar las lesiones dolosas infligidas al feto sin el consentimiento de la mujer embarazada. Esta laguna de punibilidad no tiene justificación alguna y prescinde de los desarrollos legales del derecho comparado en esta materia ${ }^{47}$.

\footnotetext{
44 Vid., Palacio, 1989 y Vives, 1995 b.

${ }^{45}$ Cfr. Suárez, 1966 y 1989.

46 Sancionar como autor de un tipo cualificado al mero cómplice, parificando su responsabilidad con la del autor, puede importar una infracción, cuando menos, del principio de proporcionalidad en sentido estricto. Vid., Vives, 1995 b.

${ }^{47}$ Es relativamente pacífico que tipificar las lesiones culposas producidas al nasciturus por la propia mujer embarazada importa una restricción adicional de la autonomía de la mujer embarazada, difícilmente justificable. Cfr., por muchos, Armin Kaufmann, 1973, p. 16 y Roxin, 2004, p. 1198. Paralelamente, si se ha optado por no tipificar el aborto imprudente (vid., sin embargo, infra $\mathrm{N}^{\circ} 6$ ),
} 
VI. Problemas que plantea la mantención de la criminalización de, al menos, un supuesto de aborto imprudente. Alternativas político-criminales más plausibles.

Ningún fundamento se proporciona para la mantención del aborto violento sin propósito de causarlo que se recepciona en el artículo $92 \mathrm{~N}^{\circ} 4$ de la PACP, casi en los mismos términos en que actualmente lo contempla el artículo 343 del vigente Código Penal. Con ello, no se hace cargo de la oscuridad que rodea la determinación de su sentido y alcance, debatidos por la doctrina, ante la posibilidad de interpretarlo incluso como un delito calificado por el resultado, como en su momento postuló la doctrina española ampliamente dominante respecto de la disposición correlativa de Código Penal español de 1848-1850: Este debió haber constituido un argumento suficiente para su supresión.

Si se consideraba merecedor de pena el comportamiento de quien maltrata o lesiona a una mujer notoriamente embarazada o conocido el estado del embarazo por el autor, pudiéndose atribuir el resultado de aborto a título de dolo eventual o imprudencia, parecía más apropiado -técnico legislativamente- haber previsto una agravante facultativa para las lesiones cometidas en contra de la mujer embarazada, solucionándose así también la existencia de un delito culposo en este ámbito.

En efecto, constituye a nuestro juicio un contrasentido político criminal optar, por un lado, por la atipicidad del aborto culposo y, por el otro, mantener sin solución de continuidad una disposición que en su interpretación más garantista sanciona una hipótesis de aborto culposo ${ }^{48}$.

pareciera coherente no tipificar tampoco las lesiones culposas causadas por terceros. Con relación a ello debe tenerse presente, sin embargo, que dichas lesiones sí tendrán proyección sobre la vida extrauterina del nasciturus. Sobre lo anterior y sobre las lesiones al feto, vid., bibliografía citada, supra, nota 10 y 37.

${ }^{48}$ Cfr., Cury, 1958, pp. 86 y ss.; Bustos, Grisolía y Politoff, 1971, pp. 214 y ss.; Etcheberry, 1998, pp. 99 y s.; Garrido, 200, pp. 109 y s.; Politoff, Matus y Ramírez, 2004, pp. 102 y s. y Bullemore/Mackinnon, 2005, p. 36. 
Horvitz y Soto - Consideraciones críticas sobre la regulación del delito de aborto...

\title{
Anexo: Disposiciones de la Propuesta Anteproyecto de Código Penal chileno
}

\author{
TÍTULO II
}

DEL ABORTO

Art. 92. El que comete un aborto será castigado:

$1^{\circ}$. Con la pena de reclusión mayor en su grado mínimo, si ejerce violencia o intimidación en la persona de la mujer embarazada;

$2^{\circ}$. Con la de reclusión menor en su grado máximo, si, no ejerciéndola, obra sin consentimiento de la mujer o lo obtiene mediante engaño;

$3^{\circ}$. Con la de reclusión menor en su grado medio, si la mujer consiente; y

$4^{\circ}$. Con la de reclusión menor en sus grados mínimo a medio, si con violencias ocasiona un aborto, siempre que no haya tenido propósito de causarlo, con tal que el estado de embarazo de la mujer sea notorio o le conste.

Art. 93. La mujer embarazada que comete su aborto o consiente que otra persona se lo cometa, será castigada con reclusión menor en su grado mínimo a medio.

Art. 94. Al facultativo que, abusando de su oficio, cometa un aborto o coopere a él, se le impondrán, respectivamente, las penas señaladas en el artículo 92, y la de inhabilitación especial para el ejercicio de su profesión en su grado máximo.

Art. 95. La tentativa y la frustración de los simples delitos comprendidos en los artículos anteriores de este párrafo son punibles, a menos que constituyan un delito más grave, caso en el cual sólo se aplicará la pena de este último. 
REJ - Revista de Estudios de la Justicia - Nº 9 - Año 2007

\section{Bibliografía}

Acosta V., Gladys: "La mujer en los códigos penales de América Latina y el Caribe hispano", en Facio/Fries, (editoras), Género y Derecho, Santiago, 1999.

Ahrens, Heinrich.: Curso de Derecho Natural o de Filosofía del Derecho formado con arreglo al estado de esta ciencia en Alemania, París, 1853.

Aldunate E., Enrique: "El efecto de irradiación de los derechos fundamentales", en J. C. Ferrada B. (coord.), La constitucionalización del derecho chileno, Santiago, 2003.

Alegre, Marcelo: “Igualitarismo, democracia y activismo judicial”, en Roberto P. Saba (editor), Los derechos fundamentales, SELA, Buenos Aires, 2001.

Alexy, Robert: "Teoría de los derechos fundamentales", en Centro de Estudios Constitucionales, Madrid, 1993.

Alexy, Robert: "Epilogo a la Teoría de los Derechos Fundamentales", en Revista Española de Derecho Constitucional, N 66, Madrid, 2002.

Alexy, Robert: "Tres escritos sobre los derechos fundamentales y la teoría de los principios", Universidad del Externado de Colombia, Bogota, 2003.

Alexy, Robert: "Collisione e bilanciamiento quale problema di base della dogmática dei diritti fondamentali”, en M. Latorre y Aspadazo, La ragionevolezza nel diritto, Gappichelli editore, Torino, 2000 .

Antolisei/ Conti: Manuale di Diritto Penale, P. E., I, $11^{\circ}$ ed., Milán, 1994.

Alvarez G., Francisco: "Bien jurídico y Constitución” en Cuadernos de Política Criminal, Madrid, 1991.

Arroyo Z., Luis: "Prohibición de aborto y Constitución", en Revista de la Facultad de Derecho de la Universidad Complutense de Madrid, $\mathrm{N}^{\circ}$ 3, 1980.

Arroyo Z., Luis: "La indicación eugenésica", en Revista de la Facultad de Derecho de la Universidad Complutense de Madrid, Monográfico No 11 (Estudios Penales en Homenaje a Luís Jiménez de Asúa), 1986.

Atria L., Fernando: "Los peligros de la Constitución". Cuadernos de Análisis Jurídico, 36, Santiago, 1997.

Atria L., Fernando: "Concepciones de la función judicial: El Caso de la Igualdad ante la Ley", en F. González y M. Viveros (editores), Igualdad, Libertad, Libertad de Expresión e Interés Público, Santiago, 2000 .

Atria L., Fernando: "Legalismo, derechos y política", en R. Saba, (editor), Los derechos fundamentales, SELA, Buenos Aires, 2001. 
Horvitz y Soto - Consideraciones críticas sobre la regulación del delito de aborto...

Atria L., Fernando: "La hora del derecho: Los derechos humanos, entre la política y el derecho", en Estudios Públicos, Nº 91, Santiago, 2003.

Atria L., Fernando: "El derecho y la contingencia de lo político", en Derecho y Humanidades, 11, 2005.

Bacigalupo Z., Enrique: Los delitos de homicidio, Bogotá, 1989.

Bacigalupo Z., Enrique: Estudios sobre la Parte Especial del Derecho Penal, $2^{\circ}$ ed., Madrid, 1994.

Bacigalupo Z., Enrique: Derecho Penal, P. G., Lima, 2004.

Bacigalupo Z., Silvina: Bacigalupo, Silvina / Gropengieber, Helmuth "La reciente reforma de la regulación de la interrupción del embarazo en Alemania y su influencia en la actual discusión española", en Cuadernos de Política Criminal, N 59, 1996.

Bajo F., Miguel: Manual de Derecho Penal, P. E., T. I., Madrid, 1986.

Bajo F., Miguel: Manual de Derecho Penal P. E. (Delitos contra las personas), Tomo I., 2 ed., Madrid, 1991.

Baño F., Miguel: El aborto en la jurisprudencia, Santiago, 1966.

Baratta, Alessandro: "El paradigma de género. De la cuestión criminal a la cuestión humana”, en H. Birgin (comp.), Las trampas del poder punitivo. El Género del Derecho Penal, Buenos Aires, 2000.

Barbero S., Marino: "Estado actual de la problemática del aborto en Europa Occidental”, en Doctrina Penal, Buenos Aires, 1985.

Barbero S., Marino: "Ingeniería genética y fecundación asistida: consideraciones políticocriminales", en Revista de Derecho penal y Criminología. U. del Externado de Colombia No 44, Bogota, Colombia. No 44, 1991.

Barros B., Enrique: “Lo público y lo privado en el derecho”, en Estudios Públicos, № 81, 2001.

Bascuñan R., Antonio: "Problemas básicos de los delitos sexuales", en Revista de Derecho, N especial, Facultad de Ciencias Jurídicas y Sociales Universidad Austral de Chile. Valdivia, agosto, 1997.

Bascuñan R., Antonio: "Límites a la prohibición y autorización legal del aborto consentido en el Derecho Constitucional Comparado", XXXI Jornadas Chilenas de Derecho Público. 8, 9 y 10 de noviembre de 2000, en Revista de Derecho Público, volumen 63, Santiago, 2001.

Bascuñan R., Antonio "La licitud del aborto consentido en el Derecho Chileno", en Derecho y Humanidades, $\mathrm{N}^{\circ} 10,2004$.

Bascuñan R., Antonio: "La píldora del día después ante la jurisprudencia", en Estudios Públicos No 95, 2004.

Bascuñan V., Antonio: “Aborto consumado. Tentativa. Nota a una Sentencia”, en Revista de Ciencias Penales, XXII, 2, 1963. 
REJ - Revista de Estudios de la Justicia - Nº 9 - Año 2007

Baumann, Jürgen: "El amparo de la vida en formación: un objetivo necesario y un método discutido", en La Reforma Penal de los Países en Desarrollo, Universidad Nacional Autónoma de México, México, 1978.

Benitez O., José Miguel: "Delitos relativos a las actuaciones conexas a las técnicas de reproducción asistida humana en el Código Penal español”, en Cuadernos de Política Criminal, 1998.

Beristain I., Antonio: "Interrupción voluntaria del embarazo: reflexiones teológico jurídicas”, en Anuario de Derecho Penaly Ciencias Penales, Madrid, 1981.

Bernal, P. Carlos: "El principio de proporcionalidad y los derechos fundamentales", $2^{\text {a }}$ edición, en Centro de Estudios Políticos y Constitucionales, Madrid, 2005.

Bernal P., Carlos: "Razionalitá, proporcionalitá e ragionevolezza nel giudizio di costituzionalitá delle leggi”, en M. La Torre y A. Sparado, La ragionevolezza nel diritto, Torino, 2000.

Beuchot, Mauricio: "Reflexiones filosóficas sobre el derecho a la vida, el aborto y el proceso inicial de la vida humana”, en M. M. Valdez (comp.), Controversias sobre el aborto, México, 2001.

Böckenforde, Ernst-Wolfgang: "Sobre la situación dogmática de los derechos fundamentales tras 40 años de la Ley Fundamental" en, del mismo, Escritos sobre Derechos Fundamentales, Baden - Baden, 1993.

Böckenforde, Ernst-Wolfgang: “Origen y cambio del concepto de Estado de Derecho” en, del mismo, Estudios sobre el Estado de Derecho y la Democracia, Madrid, 2000.

Bolle, Pierre-Henri: "Leis experimentais e directo penal" en Revista Portuguesa de Ciencia Criminal, Coimbra 5, 1, 1995.

Boronat, Mercedes: “Aborto. Reflexiones sobre una futura regulación penal de la interrupción voluntaria del embarazo”, en V. Latorre L. (coord.), Mujer y Derecho Penal, Valencia, 1995.

Borowski, Martín: "La restricción de los Derechos Fundamentales", en Revista Española de Derecho Constitucional, $\mathrm{N}^{\circ} 59,2000$.

Bórquez A., L.: Estudios sobre el aborto, Santiago, 1922.

Brage C., Joaquín: Los límites a los derechos fundamentales, Madrid, 2004.

Brock D., W.: “Libertad reproductiva: su naturaleza bases y límites”, en M. Platts (comp.), Dilemas éticos, México, 2000.

Bullemore/Mackinnon: Curso de Derecho Penal, T. III, P. E., Santiago, 2005.

Burt ,Robert: Constitución y conflicto, Eudeba, Buenos Aires, 2000.

Bustos, Juan: “Manual de Derecho Penal’, P. E., 2 ed., Barcelona, 1991.

Bustos, Juan: "Debate sobre penalización o despenalización del aborto", en Revista de la Academia de Derecho, 2, Santiago, 1993. 
Horvitz y Soto - Consideraciones críticas sobre la regulación del delito de aborto...

Calsamiglia, Albert: ¿Debe ser la moral el único criterio para legislar?, Revista $D O X A$, Alicante 13, 1993.

Canesttrari, Salvatore., "Verso una disciplina delle tecniche di procreazione medicalmente assistita?. Alla recerca del bene giuridico tra valori ideali e opzioni ideologiche", en L. Fioravanti (a cura di), La tutela penale Della persona Nuove frontiere, difficile equilibri, Milán, 2001.

Carbonell, Miguel: "Epílogo" en Tamar Pitch, Un derecho para dos. La construcción jurídica de género, sexo y sexualidad, traducción de Cristina García Pascual, Trotta, Madrid, 2003.

Carbonell, Miguel (editor): Neoconstitucionalismo (s), 2 ed., Trotta, Madrid, 2005.

Carbonell M., Juan Carlos: "Libre desarrollo de la personalidad y delitos contra la vida. Dos cuestiones: suicidio y aborto”, en Cuadernos Politica Criminal, N 45, 1991.

Carbonell, J.C./González, J.L.: en Vives A.,T. (coordinador), Comentarios al Código Penal, T. II, Valencia, 1996.

Carbonell, J.C./González, J.L.: en Vives /Boix/Orts, Derecho Penal, P. E., $3^{\circ}$ ed., Valencia, 1999.

Carbonell,J.C./González, J.L., en Vives /Orts/ Carbonell /González/Martínez-Buján : Derecho penal, P. E., Valencia, 2004.

Carassale, Santiago: Política y Derecho. Unger, Luhmann y Habermas, México, 2005.

Cardenal M., Sergi: "Homicidio intentado y lesiones consumadas en el mismo sujeto pasivo: ¿Concurso de leyes o concurso de delitos?, en Anuario de Derecho Penaly Ciencias Penales, III, 1995.

Carrió, Genaro: Recurso de amparo y técnica judicial. (Análisis crítico del caso "Kot”), Buenos Aires, 1959.

Casas B., Lidia: “La despenalización del aborto”, en Revista de la Academia de Derecho, 2, 1993.

Casas, B. Lidia "La batalla de la píldora. El acceso a la anticoncepción de emergencia en América Latina", en Derecho y Humanidades No 10, 2004.

Cea E., José Luis: Derecho Constitucional Chileno, Tomo II (Derechos, Deberes y Garantías), Santiago, 2004.

Cerezo M., José: “La regulación del aborto en el Proyecto de Nuevo Código Penal Español”, en Barbero S., M. (editor): La Reforma Penal. Cuatro cuestiones fundamentales, Madrid, 1982.

Cerezo M., José: “Observaciones críticas al Proyecto de Ley Orgánica de Código Penal”, en, del mismo, Temas fundamentales del Derecho Penal, T. II, Santa Fe, 2002.

Cerezo M., José: "Proyecto de Ley Orgánica del Código Penal de 1992”, en, del mismo, Temas fundamentales del Derecho Penal, T. II., Santa Fe, 2002.

Cirino dos Santos, Juárez: “Aborto y política criminal”, en Revista de Derecho Penal y Criminología. Univiversidad del Externado de Colombia, 2, 8, 1979. 
REJ - Revista de Estudios de la Justicia - No 9 - Año 2007

Cobo del R., Manuel/Carbonell M., Juan Carlos: en Cobo/Vives /Boix/Orts/Carbonell (coords.), Derecho Penal, P. E., 2ª ed., Valencia, 1988; $3^{a}$ ed., Valencia, 1990.

Conley T. Patrick/Mac Kenna Robert J.: “¿Acaso el derecho a la intimidad incluye el Derecho a hacerse un aborto? No: la Suprema Corte y el aborto: una opinión contraria", en Phelps/Poirier, Demandas Constitucionales Permanentes, México, 1988.

Cortés R., Manuel: "La función de la delimitación de injusto y culpabilidad en el sistema del Derecho penal”, en: Silva S., Jesús María (ed. española), Schünemann/De Figueiredo (coords.), Fundamentos de un sistema europeo del Derecho Penal, Barcelona, 1995.

Costa, Pietro: "Lo Stato di diritto: un' introduzione storica", en P. Costa/ Zolo, (a cura), Lo Stato di diritto. Storia, teoría, crítica, Milán, 2003.

Cousiño M., Luis: Derecho Penal Chileno, P. G., Tomo II, Santiago, 1979.

Croxato D., Marcelo: Las relaciones del Derecho Penal con el Derecho Civil, Santiago, 1962.

Cuerda R., Antonio: “El delito de aborto ante la Propuesta de Anteproyecto del Nuevo Código Penal”, en Documentación Jurídica N³7-40, volumen I, 1983.

Cuerda R., Antonio: "Comentario a la sentencia 53/ 1985 de 11 de abril, sobre el recurso de inconstitucionalidad del proyecto de Ley orgánica que introduce en el Código Penal un artículo 417 bis (despenalización parcial del aborto)", en Cuadernos de Política Criminal, N² 28, 1986.

Cuerda R., Antonio: "Los límites jurídico-penales de las nuevas técnicas genéticas", en Anuario de Derecho Penal y Ciencias Penales, Madrid, 1988.

Cuerda R., Antonio: “Otra vez sobre nuevas técnicas genéticas y Derecho penal”, Anuario de Derecho Penal y Ciencias Penales, 1988.

Cuerda R., Antonio “¿Es punible o sancionable la clonación terapéutica en España?”, en Homenaje al Profesor Dr. Gonzalo Rodríguez. Mourullo, Madrid, 2005.

Cury U., Enrique: "Interpretación del art. 343 del Código Penal”, en Revista Ciencias Penales., XVIII, 1958.

Da Costa A., Manuel: "El aborto en el derecho penal portugués", en Revista Doctrina Penal, 1984.

Da Costa, A. Manuel: "Merecimiento de pena y necesidad de tutela penal como referencias de una doctrina teleológico-racional del delito", en Silva/Schünemann/De Figueiredo (coords.), Fundamentos de un Sistema Europeo del Derecho Penal. Libro - Homenaje a Claus Roxin, ed. española, Barcelona, 1995

Damiao da Cunha, José Manuel: “Aborto agravado”, en J. De Figueiredo (director): Comentário Conimbricense do Código Penal, P. E., I, Coimbra, 1999.

Dedis, Nancy.: “Aborto y defensa propia”, en M. M. Valdez, Controversias sobre el aborto, México, 2001. 
Horvitz y Soto - Consideraciones críticas sobre la regulación del delito de aborto...

De Domingo, Tomás: “¿Conflictos entre derechos fundamentales?”, en Centro de Estudios Políticosy Constitucionales, Madrid, 2001.

De Faria, C. J.: “O fim da vida e o direito penal”, en Da Costa/De Faria/Miranda/Antunes (org.), Liber Discipulorum para Jorge De Figueiredo Días, Coimbra, 2003.

De Figueiredo Dias, Jorge: "Homicidio - Interrupcao da gravidez nao punivel", en del mismo (director) Comentário Conimbricense do Código Penal, P. E. I. Coimbra, 1999.

De Figueiredo D., Jorge: "Sobre os fundamentos da doutrina penal", en, del mismo, Temas basicos da doctrina penal, Coimbra, 2001.

De Rivacoba y Rivacoba, Manuel: Programa Analítico de Derecho Penal, $3^{\circ}$ ed., Valparaíso, 1981.

De Rivacoba y Rivacoba, Manuel: "Cambio de sentido en la protección y el concepto penal de la vida humana”, en Doctrina Penal, 1989.

Del Río, Raimundo: Manual de Derecho Penal, Tomo III, P. E., Santiago, 1947.

Del Rosal Juan/ Cobo del Rosal, Manuel/ Rodríguez Mourillo, Gonzalo.: Derecho Penal Español, P. E., Madrid, 1962.

Díaz P., G., "El derecho fundamental a la vida", en J. Betegón, F. Laporta, J. R. de Páramo y L. Prieto S. (coords.), en Constitución y derechos fundamentales, Madrid, 2004.

Díez R., José Luis: "El bien jurídico protegido y objeto material del delito de aborto", en M. Cobo del Rosal (Dir), M. Bajo F. (coord.): Comentarios a la Legislación penal, Tomo IX, Madrid, 1989 (a).

Díez R., José Luis: "El artículo 417 bis del Código Penal y su naturaleza jurídica", en M. Cobo del Rosal (Dir), M. Bajo F. (coord.): Comentarios a la Legislación penal, Tomo IX, Madrid, 1989 (b).

Díez R., José Luis: “Análisis de los elementos de la causa de justificación del artículo 417 bis del Código Penal”, en M. Cobo del Rosal (Dir), M. Bajo F. (coord.): Comentarios a la Legislación penal, Tomo IX, Madrid, 1989.

Díez R., José Luis: "Fundamento y naturaleza del art. 417 bis y su relación con las eximentes genéricas", en J. L. de la Cuesta, I. Dendaluze y E. Echeburúa (comps.), Criminología y Derecho Penal al servicio de la persona (Libro-Homenaje al Profesor Antonio Beristain), San Sebastián, 1989 (d).

Díez R., José Luis: "La categoría de la antijuridicidad en Derecho Penal”, en D. M. Luzón P. y S. Mir P. (coords.), Causas de justificación y de atipicidad en derecho penal, Navarra, 1995.

Díez R., José Luis: La racionalidad de las leyes penales, Madrid, 2003.

Díez R., José Luis: "El control de constitucionalidad de las leyes penales", en Revista Española de Derecho Constitucional $\mathrm{N}^{\circ} 75,2005$. 
REJ - Revista de Estudios de la Justicia - No 9 - Año 2007

Dolcini, Emilio: "Embrione, pre-embrione, ootide: nodi interpretativi nella disciplina della procreazione medicalmente assitita (L. 19 febbraio 2004 n. 40)", en Rivista Italiana di Diritto Penale e Procedura Penale, 2, 2004.

Donccel, Joseph F.: "Un punto de vista Católico Liberal”, en M.M Valdez, (comp.) Controversias sobre el aborto, México, 2001.

Donini, Massimo: "Método democrático e método scientifico nell rapporto fra diritto penale e politica" en, del mismo, Alla ricerca di un disegno. Scritti sulle riforme penali in Italia, Padova, 2003 (b).

Donini, Massimo: "Ragioni e limiti della fondazione del diritto penale sulla Carta Costituzionale", en, del mismo, Alla ricerca di un disegno. Scritti sulle riforme penali in Italia, Padova, 2003.

Donna, Edgardo: Derecho Penal, P. E., T. I., Buenos Aires, 1999.

Dworkin, Ronald: El dominio de la vida. Una discusión acerca del aborto, la eutanasia y la libertad individual, Barcelona, 1994.

Escuchuri A., Estrella: Teoría del concurso de leyes y de delitos. Bases para una revisión crítica, Granada, 2005.

Eser, Albin: "Reforma de la regulación del aborto en el Derecho Penal Alemán: evolución y primeras experiencias", en Criminología y Derecho Penal al servicio de la persona (Libro Homenaje al profesor Antonio Beristain), San Sebastián, 1989 (a).

Eser, Albin: "Status dell' embrione umano da un punto di vista giuridico", en Politica del Diritto, 1989 (b).

Eser, Albin: "Entre la "santidad" y la "calidad" de la vida. Sobre las transformaciones en la protección, jurídico penal de la vida", en, del mismo, Nuevos horizontes en la ciencia penal, Buenos Aires, 1999 (a).

Eser, Albin: "Reforma de la regulación Alemana sobre el aborto desde una perspectiva de Derecho comparado", en, del mismo, Nuevos horizontes en la ciencia penal, Buenos Aires, 1999 (b).

Eser, Albin: “Amenazas a la vida humana en su comienzo", en, del mismo, Nuevos horizontes en la ciencia penal, Buenos Aires, 1999 (c).

Eser, Albin: "La evolución del Derecho penal alemán en las últimas décadas del S. XX”, L. Arroyo e I. Berdugo, Homenaje al Dr. Marino Barbero Santos. In Memoriam, Cuenca, 2001.

Eusebi, Luciano: "La tutela penale della vita prenatale", en Rivista Italiana di Diritto e Procedura Penale, 1988.

Eusebi, Luciano: "Beni penalmente rilevanti e tecniche di procreazione", en L. Fioravanti, (a cura di) La tutela penale della persona. Nuove frontiere, difficili equilibri, Milán, 2001.

Etcheberry O., Alfredo: Derecho penal, Tomo III, P. E., 1ª ed. Santiago, 1965; 2 ed. Santiago, 1976; 3 ed. Santiago, 1998. 
Horvitz y Soto - Consideraciones críticas sobre la regulación del delito de aborto...

Facio Alda: "Metodología para el análisis de genero del fenómeno legal", en A. Facio y 1. Fries, (eds.), Género y Derecho, Santiago, 1999.

Farré T., Elena, "Sobre el concepto de aborto y su delimitación de los delitos contra la vida humana independiente", en Anuario de Derecho Penaly Ciencias Penales; 1990

Farré T., Elena: "Dolo eventual, imprudencia y formas imperfectas de ejecución", en S. Mir P. y otros, "Comentarios a la jurisprudencia penal del Tribunal Supremo", Barcelona, 1987.

Farrell, Martín: La ética del aborto y la eutanasia, Buenos Aires, 1985.

Farrell, Martín: El derecho liberal, Buenos Aires, 1998.

Flores M., Fátima: “El delito de lesiones al feto en el Código Penal español de 1995”, en Revista de Derecho y Genoma Humano, 5, 1996.

Feijóo, Bernardo: en M. Bajo F. y otros, Compendio de Derecho Penal, P. E., I, Madrid, 2003.

Femanía L., P.J.: "Status" jurídico civil del embrión bumano, con especial consideración al concebido "in vitro", Madrid, 1999.

Fernández Bautista, Silvia: "Delitos contra la vida humana en formación. Delitos de manipulaciones genéticas", en: M. Corcoy B., Manual práctico de derecho penal, P. E., 2 ed., Valencia, 2004.

Ferrajoli, Luigi: "Igualdad y diferencia" en, del mismo, Derechos y garantías. La Ley del más débil, Madrid, 1999.

Ferrajoli, Luigi: "La cuestión del embrión entre derecho y moral", en Jueces para la Democracia. (Información y debate) N 44, 2002.

Ferrajoli, Luigi: "Lo Stato di diritto fra passato e futuro", en P. Costa y D. Zolo (a cura di): Lo Stato di diritto. Storia, teoría, crítica, Milán, 2003 (a).

Ferrajoli, Luigi: "Prólogo" en Tamar Pitch: Un derecho para dos. La construcción jurídica de género, sexo y sexualidad, traducción de Cristina García Pascual, Trotta, Madrid, 2003 (b).

Ferrando, Gilda: "La procreazione assistita: modelli di disciplina a confronto", en L. Fioravanti (a cura di): La tutela penale della persona. Nuove frontiere, difficili equilibri, Milán, 2001.

Ferreres C. Víctor: "La eficacia de los derechos constitucionales frente a particulares", en Roberto P. Saba (editor), Los derechos fundamentales, SELA, Buenos Aires, 2001.

Ferreres C., Víctor: El principio de taxatividad en materia penal y el valor normativo de la Jurisprudencia (una perspectiva constitucional), Madrid, 2002.

Ferreres C., Víctor: "Las consecuencias de centralizar el control del constitucionalidad de la ley en un tribunal especial. Algunas reflexiones acerca el activismo judicial”, en R. Saba (editor), Los límites de la democracia, SELA, Buenos Aires, 2004. 
REJ - Revista de Estudios de la Justicia - Nº 9 - Año 2007

Feuerbach, Paul J. A. von: Tratado de Derecho penal común vigente en Alemania, tr. de la $14^{\circ}$ ed. alemana, (1847) Buenos Aires, 1989.

Feuerbach, Paul J.A. von: Anti - Hobbes. Overo I ilimiti del podere supreme e il diritto coattivo dei cittadini contro il sovrano (orig., 1798), Milano, 1972.

Feuillard, Christian: "La interrupción voluntaria del embarazo en el derecho penal francés”, en Revista de Derecho Penal, 1984.

Fiandaca, Giovanni: "Il bene "giuridico", come problema teorico e come criterio di politica criminale”, en Rivista Italiana di Diritto Penale e Procedura Penale, 1982.

Fiandaca, Giovanni: “L'offensivita é un principio codificable?", en A. M. Stile (a cura di), La reforma della parte generale del Codice Penale. La posizione della doctrina su progetto grosso, jovene, 2003.

Finnis, John: "Derechos e injusticias del aborto: réplica a Judith Tomson", en R. M. Dworkin (comp.), La filosofía del derecho, México, 1977.

Fioravanti, Laura: "La tutela penale della persona: nuove frontiere difficili equilibri", en: L. Fioravanti (a cura di), La tutela penale della persona. Nuove frontiere, difficili equilibri, Milán, 2001.

Flamigni, Carlo: "Lo statuto dell' embrione tra giudizi morali e sviluppo tecnologico", en L. Fioravanti (a cura di): La tutela penale della persona. Nuove frontiere, difficili equilibri, Milán, 2001.

Foot, Philippa: "El problema del aborto y la doctrina del doble efecto" en, de la misma, Las virtudes y los vicios y otros ensayos de filosofía moral, México, 1994.

Fries/ Matus: “Sexualidad y reproducción, una legislación para el control: el caso chileno”, en A. Facio y L. Fries (eds.), Género y Derecho, Santiago, 1999.

Fries/ Matus: La ley el delito, Santiago, 2000.

Fuenzalida, Alejandro: Concordancias y comentarios del Código Penal Chileno, Lima, 1883.

García Alvarez, A.: “¿Es innecesario el delito de lesiones al feto?, en Revista de Derecho Penal, 1, 2000.

García Arán, Mercedes.: en J. Córdoba R. y M. García A. (directores): Comentarios al Código Penal. Parte Especial, T. I., Madrid, Barcelona, 2004.

García Albero, Ramón: Non bis in ídem. Materialy concurso de leyes penales, Barcelona, 1995.

García Gonzales, C.: Limites penales a los últimos avances de la ingeniería genética aplicada al ser humano, Madrid, 2001.

García Victoria, Ana: “El delito de aborto consentido, a la luz de las legislaciones actuales", en Anuario de Derecho Penaly Ciencias Penales, 1981.

García-Huidobro, Joaquín: "La dignidad del hombre” en García-Huidobro/Martínez/Núñez, Lecciones de derechos bumanos, Valparaíso, 1997. 
Horvitz y Soto - Consideraciones críticas sobre la regulación del delito de aborto...

Garrido Montt, Mario: Derecho Penal, Tomo III, P.E., 2 ed. Santiago, 2002.

Garzón V. Ernesto: “Las funciones del derecho en América Latina”, en, del mismo, Derecho, ética y politica, Madrid, 1993.

Gianformaggio,Letizia: L'interpretazione Della Costituzione tra applicazione di regole ed argomentazione basata su principi, en Rivista Internazionale di Filosofia del Diritto, 1985.

Gimbernat, O. Enrique: Estudios de Derecho penal, $3^{a}$ ed. Madrid, 1990.

Gimbernat, O. Enrique: "Algunos aspectos de la reciente doctrina jurisprudencial sobre los delitos contra la vida", en Revista de Derecho Penal y Criminología. Universidad del Externado de Colombia., $41-42,1990$.

Godinho Vaz Patto, Pedro María "Os sentido da criminalizacao do aborto. A justar a lei sem sacrificar os principios”, en Revista Portuguesa de Ciencia Criminal, N 1, año 15, 2005.

González C., José Luis: "Manipulación genética y reproducción asistida en la reforma penal española", en Revista de Derecho y Genoma Humano, 3, 1995.

González R., Juan José: "Italia: Cuatro referéndum afectantes a materias penales", Anuario de Derecho Penaly Ciencias Penales, T. II y III, 1981.

González R., Juan José: en M. Cobo del Rosal (Director), Manual de Derecho Penal, P. E., I, Madrid, 1993.

González R., Juan José: "El aborto”, en M. Cobo del Rosal (Director), Curso de Derecho penal español, P. E., tomo I, Madrid, 1996.

González R., Juan José: en M. Cobo del Rosal (Director), Compendio de Derecho Penal Español, P. E., Madrid, 2000.

González R., Juan José: en M. Cobo del Rosal (Director), Comentarios al Código Penal, T, V., Madrid, 2002.

González R., Juan José: en M. Cobo del Rosal (coordinador), C. Carmona S., J. J. González R. y otros, Derecho penal español, P. E., Madrid, 2004.

Gomes Cantilho, José Joaquim: Direito Constitucional e Teoria da Constitucao , $6^{\circ}$ ed., Coimbra, 2002.

Gössel, Karl Heinz : "La reforma del delito de aborto en Alemania", en Cuadernos de Política Criminal, $\mathrm{N}^{\circ}$ 4, 1978.

Gracia M., Luis: en J. L. Diez R. y L. Gracia M., Delitos contra bienes juridicos fundamentales. Vida bumana independiente y libertad, Valencia, 1993.

Gracia M., Luis: "De las lesiones al feto”, en J. L. Díez R - L. Gracia M., (coords.), Comentarios al Código Penal, P. E., Tomo I, Valencia, 1997.

Gracia M. Luis/ Escuchuri A., Estrella: Los delitos de lesiones al feto y los relativos a la manipulación genética: Estudio del los Títulos IV y V del Libro II, del Código Penal, Valencia, 2005. 
REJ - Revista de Estudios de la Justicia - Nº 9 - Año 2007

Granados P., C. "Objeto material en los delitos contra las personas", en Manuales de formación continuada, 3. Delitos contra las personas, CGPJ., Madrid, 1999.

Grisolía, Francisco/ Bustos, Juan/ Politoff, Sergio: Derecho Penal Chileno, Tomo I, P. E., Santiago 1971.

Grosso C., Federico: "La interrupción voluntaria del embarazo" en Revista de Derecho Penal, 1984.

Gunther, Hans - Ludwig: "La clasificación de las causas de justificación en Derecho Penal", en D. M. Luzón P. y S. Mir p. (coords.): Causas de atipicidad y causas de justificación, Madrid, 1995

Gutiérrez G., Ignacio: Dignidad de la persona y derechos fundamentales, Madrid, 2005.

Häberle, Peter: La garantía del contenido esencial de los derechos fundamentales, Madrid, 2003.

Habermas, Jürgen: "Derecho y moral (Tanner Lectures, 1986)", en, el mismo, Facticidad y valide₹: Sobre el derecho y el Estado democrático en términos de teoría del discurso, Madrid, 1988.

Habermas, Jürgen: El discurso filosófico de la modernidad, Buenos Aires, 1989.

Habermas, Jürgen: "Derecho y moral (dos lecciones)", en D. Sobrerilla, (compilador), El derecho, la política y la ética (Actas del I Coloquio Alemán - Latinoamericano de filosofía, 1984), México, 1991.

Habermas, Jürgen: Morale, diritto, politica, Torino, 1992.

Habermas, Jürgen: El futuro de la naturalęa humana. ¿Hacia una engenesia liberal?, Barcelona, 2002.

Hernández, P. José Ulises: "La protección penal del embrión preimplantatorio", en C. M. Romeo C. (editor), Genética y Derecho Penal. Previsiones en el Código Penal Español de 1995, Bilbao Granada, 2001.

Herrera, R. Susana: “El aborto inducido. ¿Víctimas o victimarias?”, Santiago, 2004.

Herrera I., Alejandro: El problema ético del aborto, en M. M. Valdez, (comp.), Controversias sobre el aborto, México, 2001.

Heymann, Phillip/ Barzelai, Douglas: "¿Acaso el derecho a la intimidad incluye el derecho a hacerse un aborto?. Sí: Roe v/s Wade y sus crítícas", en G.A Phelps y otro, R.A. Poirer, "Demandas constitucionales permanentes. Debates contemporáneos sobre libertades civiles", México, 1988.

Hirsch, Hans Joachim: "La reforma de los preceptos sobre la interrupción del embarazo en la República Federal Alemana", en La reforma penal. Cuatro cuestiones fundamentales, Madrid, 1992.

Hoerster, Norbert: “Acerca del significado del principio de la dignidad humana”, en, del mismo, En defensa del positivismo jurídico, Barcelona, 1992 (a).

Hoerster, Norbert: El infanticidio y el derecho a la vida de las personas, en, del mismo, En defensa del positivismo jurídico, Barcelona, 1992 (b). 
Horvitz y Soto - Consideraciones críticas sobre la regulación del delito de aborto...

Hoerster, Norbert: "La prohibición del aborto: presupuestos religiosos y consecuencias jurídico políticas", en, del mismo, En defensa del positivismo jurídico, Barcelona, 1992 (c).

Huerta T., Susana: Aborto con resultado muerte o lesiones graves, Madrid, 1977.

Huerta T., Susana: “Criterios para la reforma del delito de aborto", en Cuadernos de Política Criminal, $\mathrm{N}^{\circ} 8,1979$.

Huerta T., Susana: "Los delitos de aborto, lesiones al feto y manipulaciones genéticas en el Código Penal de 1995”, en A. Asúa B. (ED) Jornadas sobre el nuevo Código Penal de 1995, Gipuzkoa, s/f.

Huerta T., Susana: "De ciertas incongruencias y aparentes paradojas en los delitos de lesiones al feto”, en A. Quintero O. - F. Morales P., El Nuevo Derecho Penal Español. Estudios Penales en Memoria del Profesor José Manuel Muñiz, Pamplona, 2001.

Hurtado P., José: Manual de Derecho Penal, P. E., Lima, 1982.

Hurtado P., José: «Infractions contre la vie et L'integrité corporelle », 2 ed., revisée et mise a jour. Droit Pénal, P. E., 1, 1988.

Ibáñez y García V., José Luis: La despenalización del aborto voluntario en el o caso del siglo XX, Madrid, 1992.

Jakobs, Günther: “¿Existe un aborto lícito de personas?”, en, del mismo, Dogmática de derecho penal y la configuración normativa de la sociedad, Madrid, 2004.

Jescheck, Hans Heinrich/ Weigend, Thomas: Tratado de derecho penal, P.G., Granada, 2002.

Jiménez C., Javier: "Interpretación conforme a la Constitución”, en Enciclopedia Jurídica Básica III, Madrid, 1995.

Jorge B., Agustín: "El aborto en la reforma penal española", en: Estudios Penales y Criminológicos, XVII, 1994.

Jorge B., Agustín: en Rodríguez M. (director) y A. Jorge B. (coord.), Comentarios al Código Penal, Madrid, 1997.

Kaufmann, Armin: "Tipicidad y causación en el procedimiento de Contengan. Consecuencias para el derecho en vigor y la legislación", en Nuevo Pensamiento Penal, 2, 1973.

Kaufmann, Arthur: “¿Relativización de la protección jurídica de la vida?”, en Cuadernos de Política Criminal, $\mathrm{N}^{\circ} 31,1987$

Labatut G., Gustavo: Derecho Penal, Tomo II, P. E., Santiago, 1951.

Labatut G. Gustavo: Derecho Penal, T. II, P. E., $7^{\circ}$ ed., actualizada por J. Zenteno V., Santiago, 1983. 
REJ - Revista de Estudios de la Justicia - No 9 - Año 2007

Lacadena C., Juan Ramón: "Consideraciones genético - biológicas sobre el desarrollo embrionario humano", en: C. Romeo C., Genética bumana. Fundamentos para el estudio de los efectos sociales de las investigaciones sobre el genoma bumano, Bilbao - Granada, 1995.

Lagos L., Claudia: Aborto en Chile, Santiago, 2001

Lamo De Espinosa M., Emilio: Delitos sin víctima. Orden social y ambivalencia moral, Madrid, 1989.

Landrove D., Gerardo: "Voluntaria interrupción del embarazo y derecho penal", en Cuadernos de Política Criminal, 1980.

Landrove D., Gerardo: “La tímida despenalización del aborto en España”, en Estudios Penales y Criminológicos, X, 1987.

Laporta S., Francisco: “El principio de igualdad”, en Sistema $N^{\circ}$ 67, 1985.

Laporta S., Francisco: "Ética y derecho”, en V. Camps, (comp.), Historia de la ética, vol. III. La ética contemporánea, Barcelona, 1989.

Larrandart Lucila, E.: “Control social, derecho penal y género", en H. Birgin (comp.),"Las trampas del poder punitivo. El género del Derecho Penal, Buenos Aires, 2000.

Lascuraín, S., J. A.: en G. Rodríguez M. (director) y A. Jorge B. (coord.) "Las trampas del poder punitivo. El género del Derecho penal", Buenos Aires, 2000.

Latorre L., Virgilio: (coord.), Mujer y Derecho Penal, Valencia, 1995.

Latorre L., Virgilio: “Lesiones al feto", en, del mismo (coord.), Mujer y Derecho Penal, Valencia, 1995.

Laurenzo, C. Patricia: El aborto no punible, Barcelona, 1990.

Laurenzo, C. Patricia: "Del aborto", en Díez/Gracia (coords.), Comentarios al Código Penal, P.E., Tomo I, Valencia, 1997.

Longo, P. y Ghedini, N. (a cura di), Commentario Costituzionale al Codice Penale e alle leggi di de penalizzazione, Padova, 2000.

López B. de Q., Jacobo., en López/Cobos/Rodríguez R., Manual de Derecho Penal, P. E., T. I, Madrid, 1990.

López B., Héctor: Decisiones interpretativas en el control de constitucionalidad de la Ley, Valencia, 2004.

Lora D., Pablo de: "El último libro de Dworkin: aborto y eutanasia”, en Sistema Nº117, 1983.

Lüttger, Hans: "La distinción del embrión y el feto frente a la calidad de persona en el proceso de "Contergan"”, en, del mismo, Medicina y Derecho Penal: inseminación artificial bumana, anticonceptivos y aborto, embrión, feto y persona, concepto de muerte en el derecho penal, trasplante de órganos, traducción de Enrique Bacigalupo, Madrid, Edersa, 1984. 
Horvitz y Soto - Consideraciones críticas sobre la regulación del delito de aborto...

Lüttger, Hans: "Las técnicas obstreticias y la noción de persona desde el punto de vista penal", en, del mismo, Medicina y Derecho Penal, Madrid, Edersa, 1984.

Lüttger, Hans: "La nueva distinción entre anticonceptivos y aborto desde el punto de vista biológico y jurídico penal”, en, del mismo, Medicina y Derecho Penal, Madrid, Edersa, 1984.

Luzón P., Diego: 1991: "Indicaciones y causas de justificación en el aborto", en, del mismo, Estudios penales, Barcelona, 1991.

Luzón P., Diego: "Legitima defensa y estado de necesidad defensivo", en del mismo, Estudios penales, Barcelona, 1991.

Luzón P., Diego: "Causas de atipicidad y causas de justificación”, en D. M. Luzón P. y S. Mir P. (coords.), Causas de atipicidad y causas de justificación, Madrid, 1995

Luzón, P. Diego: "La relación del merecimiento y de la necesidad de pena con la estructura del delito", en Silva S. (ed. española), B. Schunemann/Figueiredo D., (coords.), "Fundamentos de un sistema europeo del Derecho Penal”.Libro homenaje a Claus Roxin, Ed. Española, Barcelona, 1995

Luzón P., Diego: Curso de derecho penal, P.G., I, Madrid, 1996.

Luzón P., Diego: ”Aborto", en D.M. Luzón P. (dir.), Enciclopedia Penal Básica, Granada, 2002.

Luzón P., Diego: “Homicidio (voz)”, en: Enciclopedia Penal Básica, Granada, 2002.

Mac Kinnon, Catherine: Hacia una teoría feminista del Estado, Madrid, 1995.

Mac Kinnon, Catherine "El liberalismo y la muerte del feminismo", en Actuel Marx. Intervenciones, 4, 2005.

Magro, B.: "Ética laica e tutela della vita umana: riflessioni sul principio di laicatá in diritto penale", en Rivista Italiana di Diritto Penale e Procedura Penale, 4, 1994.

Manna, Adelmo.: "Tutela degli embrión e Diritto penale: a proposito di un progetto di legge tudesco", en Politica del diritto, 1990.

Mantovani, Ferrando: "Problemas penales de la manipulación genética”, en Doctrina Penal, 1986.

Mantovani, Ferrando:"Problema giuridici delle manipolazioni genetiche", en Revista de Derecho Penal y Criminología (Univ. Externado de Colombia), 50, 1993.

Mantovani, Ferrando: "I dilitti contro l' essere umano", en: Evoluzione e reforma del Diritto e Della procedura penale. Studi in Onore di Giuliano Vassalli, V. I., Diritto Penale, Milán, 1991.

Mapelli C., Borja: "Entre el homicidio y las lesiones", en Revista Peruana de Ciencias Penales, N 5, III, 1997.

Marquis, Donald: “¿Por qué es inmoral el aborto?”, en M. M. Valdez (comp.) Controversias sobre el aborto, México, 2001. 
REJ - Revista de Estudios de la Justicia - Nº 9 - Año 2007

Maturana R., Humberto: “¿Cuándo se es humano?” en, del mismo, "El sentido de lo humano”, Santiago, 1991.

Mendoza B., Blanca: "La delimitación del ámbito de aplicación del delito de lesiones al feto en el sistema del Código Penal de protección de la salud y la vida", en Homenaje al Prof. Dr. Gonzalo Rodríguez. Mourullo, Madrid, 2005.

Merkel, Adolf: Derecho Penal, T.II. P.E., Madrid, s/f.

Mezger, Edmundo: Derecho Penal. Libro de Estudio, P. E., Buenos Aires, 1958.

Mir P., Santiago: "Aborto estado de necesidad y Constitución. Comentario a la Sentencia de la Audiencia de Bilbao de 24 de marzo de 1982", en Revista Jurídica de Cataluña, I, 1981.

Mir P., Santiago: “Objeto del delito” en Nueva Enciclopedia Jurídica Seix, XVII, 1982.

Mir P., Santiago: "Sobre el tipo subjetivo del concurso de delitos", en "Comentarios a la jurisprudencia penal del Tribunal Supremo”, Barcelona, 1987

Moccia, Sergio: "Bioética o $<<$ biodiritto $>>$. Gli intervente dell' uomo sulla vita in fieri di fronte al sistema penale dello Stato Sociale di Diritto", en Rivista Italiana di Diritto Penale e Procedura Penale 3 , 1990.

Moccia, Sergio: "Un infelice compromesso: il Testo unificato delle proponte di legge in materia di procreazione medicalmente assistita”, in Critica del diritto, 1998.

Moccia, Sergio.: La promesa non mantenuta" ( Ruolo e prospettive del principio di determinatezza / taxativita nel sistema penale italiano), Napoli, 2001.

Moccia, Sergio: El Derecho penal entre sery valor, Buenos Aires, 2003.

Mohor A., Salvador: "Reflexiones en torno a la prohibición del aborto en Chile", en XX Jornadas Chilenas de Derecho Público (26 y 27 de octubre de 1989), Tomo II, Valparaíso, 1990.

Molina Fernández, Fernando: "El estado de necesidad. (Aproximación a un sistema de causas de Justificación)", en Revista de Derecho Penal y Criminología. Universidad Nacional de Educación a Distancia, $\mathrm{N}^{\mathrm{o}} 1,2000$.

Montano, Pedro: "La responsabilidad de médicos y científicos ante las nuevas tecnologías biogenéticas", en, J. M. Silva S. (ed.), Política criminal y nuevo derecho penal. Libro Homenaje a Claus Roxin, Barcelona, 1997.

Morales Prat, Fermín: en G. Quintero O. (dir.) y F. Morales P. (coord.) Comentarios a la Parte Especial del Derecho Penal, $2^{\circ}$ ed., Pamplona, 2001.

Muñoz C., Francisco: Derecho penal, P.E., 14 ed.. Valencia, 2002.

Muñoz L., José: “Obligaciones constitucionales de incriminación y derecho penal simbólico”, en Revista de Derecho y Proceso Penal, No 6, 2001. 
Horvitz y Soto - Consideraciones críticas sobre la regulación del delito de aborto...

Musco, Enzo: "Consenso e legislazione penale", en Rivista Italiana di Diritto Penale e Procedura Penale, 1,1993

Musco, Enzo: L'illusione penalistica, Milán, 2004.

Nino, Carlos Santiago: "La autonomía Constitucional", en C.F. Rosenkrantz y otros, en La autonomía personal, Cuadernos y Debates 37, Centro de Estudios Constitucionales, Madrid, 1992.

Novoa A., Eduardo: "El delito de homicidio y la intención de matar", en Revista de Ciencias Penales., VIII, No 3, 1945.

Novoa A., Eduardo: El comienzo de la existencia humana y su protección jurídica, Santiago, 1969.

Novoa A., Eduardo: "Infanticidio. Nota a una Sentencia", en Revista de Ciencias Penales $N^{o} 2$, XXXII, 1973.

Novoa A., Eduardo: "Aborto seguido de muerte. Nota a una sentencia", en: Revista de Ciencias Penales, 1960.

Núñez B., Ruperto: "Significación y trascendencia actual del sistema romano de la "portio mulieris", en el aborto consentido", en Anuario de Derecho Penaly Ciencias Penales, 1992.

Núñez, Manuel Antonio: "El derecho a la vida o el deber de respetar la vida", en J. García .Huidobro /J. I. Martínez y M. A. Núñez, en "Lecciones de derechos humanos”, Valparaíso, 1997.

Ollero T., Andrés: Derecho a la vida y derecho a la muerte, Madrid, 1994.

Olmedo C., Miguel: “’De las lesiones al feto. Artículos 157 a 158”, en: M. Cobo del R. (dir.), Comentarios al Código Penal, T.V., Madrid, 1999.

Palacio Sánchez Izquierdo, José Ricardo: "La circunstancia cualificativa de profesionalidad en el delito de aborto”, en: J. L. de la Cuesta, I. Dendaluze y E. Echaburúa, Criminología y Derecho Penal al servicio de la persona. Libro - Homenaje al Profesor Antonio Beristain, San Sebastián, 1989.

Palazzo, Francesco: "Scienza penale e produzione legislativa: Paradossi e contraddizioni di un rapporto problemático", en Rivista Italiana di Diritto Penale e Procedura Penale”, N 3, 1997.

Palazzo, Francesco: "Ofensivitá e ragionevolezza nel controllo di costituzionalitá sul contenuto delle leggi penali”, en: Rivista Italiana de Diritto Penale e Procedure Penale, N², 1998.

Paliero, Carlo Enrico: "Diritto penale e consenso sociale", en: G. Fiandaca y otros: Verso un nuevo Codice Penale. (Tai del Convengo promosso dal "Centro studi giuridici e sociali Cesare Terranov". Palermo, 7 a 10 novenbre 1991), Milán, 1993.

Panagia, Salvatore: "Dell metodo e della crisi del diritto penale", en Rivista Italiana di Diritto Penale e Procedura Penale, 3, 1997.

Pannain, Remo: “Aborto. Diritto penale”, en Novísimo Digesto Italiano, V. I, 1958. 
REJ - Revista de Estudios de la Justicia - No 9 - Año 2007

Peñaranda R., Enrique: "La protección de la vida y la salud humana entre sus fases prenatal y postnatal de desarrollo", en: Revista de Derecho Penal y Criminología, Universidad Nacional de Educación a Distancia, 2 época, N 11, 2003.

Peñaranda R., Enrique: en, M. Bajo F., E. Peñaranda R. y otros, Compendio de Derecho penal, P. E., I, Madrid, 2003.

Peñaranda R., Enrique: "Fases en el desarrollo de la vida y grados de su protección. A propósito del tratamiento jurídico- penal del diagnóstico preimplantatorio", en: Homenaje al Prof. Dr. Gonzalo Rodríguez, Mourullo, Madrid, 2005.

Pérez M., Mercedes: “Lesiones al feto (voz)”, en D. M. Luzón P. (dir.), "Enciclopedia Penal Básica”, Granada, 2002.

Pérez M., Mercedes: en M. Bajo F., M. Pérez M. y otros, Compendio de Derecho Penal, P. E., Madrid, 2003.

Pérez del Valle, Carlos: "Del aborto. Artículos 144, 145 y 146", en Comentarios al Código Penal, dirigidos por Manuel Cobo Del Rosal, Madrid, 1999.

Pérez del Valle, Carlos: "Finalidad terapéutica e investigación genética. (A propósito de la consideración jurídica del embrión), en, del mismo (dir.) Genética y Derecho, Cuadernos de Derecho Judicial, VI, 2004.

Peris R., Jaime: La regulación penal de la manipulación genética en España. (Principios fundamentales y tipificación de las genotecnologías), Madrid, 1995.

Peukert, Wolfgang: "Derechos humanos en el Derecho internacional y la protección del ser humano por nacer", en Doctrina Penal, 1990.

Phelps, Glenn: "Roe v/s Wade: ¿acaso el derecho a la intimidad incluye en derecho a hacerse un aborto?", en G. A. Phelps y R.A. Poirer, "Demandas constitucionales permanentes. Debates contemporáneos sobre libertades civiles”, México, 1988.

Pitch Tamar: "Un derecho para dos. La construcción Jurídica de género, sexo y sexualidad", Madrid, 2003.

Politoff, S./ Matus, J.P./ Ramírez, M.C.: Lecciones de derecho penal chileno, P.E., Santiago, 2004.

Politoff, S./ Matus, J.P./ Ramírez, M.C.: : "Lecciones de Derecho Penal", P. E., $2^{\mathrm{a}}$ ed., Santiago, 2006.

Possenti, Vittorio: “¿Es el embrión persona?. Sobre el estatuto ontológico del embrión humano”, en C.I. Manzini y P. Serna, (eds.), El derecho a la vida, Pamplona, 1988.

Prieto S., Luis: "El constitucionalismo de los derechos", en Revista Española de Derecho Constitucional 24, 71, 2004.

Pulitano, Domenico: “Obblighi costituzionali di tutela penale?”, en Rivista Italiana di Diritto Penale e Procedura Penale, 1983. 
Horvitz y Soto - Consideraciones críticas sobre la regulación del delito de aborto...

Pulitano, Domenico: "Nell laboratorio della riforma del Codice Penale", en Rivista Italiana di Diritto Penale e Procedura Penale., 2001.

Queralt, Joan: Derecho Penal Español, P. E., Barcelona, 1996.

Ramón R., E.duardo: El delito de lesiones al feto, Granada, 2002.

Requejo C., Carmen: "'Cortengan": la historia de un delito", en Cuadernos de Politica Criminal, No 66, 1998.

Requena B., Mariano (ed.): Aborto inducido en Chile, Santiago, 1990.

Ricciotti, R. / Strano. L.: en Alberto Crespi, Federico Stella y Giuseppe Zuccala: Commentario Breve al Codice Penale, Milan, 1999.

Riz, Roland: "Bioética - Fiuet - Clonazione. Tutela della persona e della vita", en L'Indice Penale, 2000 .

Rodríguez C., Luis: "El delito de aborto frente a la Constitución de 1980", en Revista de Derecho de la Universidad Católica de Valparaíso, N 14, 1991, 1992.

Rodríguez, Graciela A., 'Recensión a Martín Dell' Osso, De Palma, Lore, Norelli, Piva: L' aborto: aspetti medico - legali della nueva disciplina, Dott. A. Giuffré, Milano, 1979”, en: Doctrina Penal, 1980.

Rodríguez M., Gonzalo: "Derecho a la vida y a la integridad personal y abolición de la pena de muerte", en: M. Cobo del Rosal (dir), M. Bajo F. (coord.), "Comentarios a la Legislación penal, I. Derecho penaly Constitución", Madrid, 1982.

Rodríguez M., Gonzalo: "Protección Constitucional de la vida", en: "Repercusiones de la Constitución en el Derecho Penal. Semana de Derecho Penal en Memoria del Prof. Julian Pereda S. J.”, Bilbao, 1983.

Rodríguez M., Gonzalo: "El aborto. La Sentencia del Tribunal Constitucional Español desde las perspectivas Constitucional y Penal”, en: A. López P. (comp.), División de poderes e interpretación. Hacia una teoria de la praxis Constitucional, Madrid, 1987.

Rodríguez M., María José: “Algunas consideraciones acerca del bien jurídico protegido en el delito de lesiones al feto" en: Revista de Derecho Penal y Criminología. Universidad Nacional de Educación a Distancia, 2 ${ }^{\circ}$ 6, 1996.

Rodríguez R., Luis: en M. A. Cobos Gómez de Linares, J. López Barja de Quiroga y L. Rodríguez Ramos, Manual de Derecho Penal, P. E., T. I., Madrid, 1990.

Romano, M. / Stella, F.: “Aborto e legge penale”, en: Revista JUS, 1975.

Romano, Mario.: “Scolarizzazione Diritto penale moderno e sistema dei reati”, en Rivista Italiana di Diritto Penale e Procedura Penale, 1981.

Romano, Mario: "Legislazione penale e consenso sociale”, en Revista JUS, 3, 1985. 
REJ - Revista de Estudios de la Justicia - No 9 - Año 2007

Romano, Mario: "Legislazione penale e tutela della persona umana (contributo alla revisione del titolo XII del Codice Penale)", en Rivista Italiana di Diritto Penale e Procedura Penale., 1, 1989.

Romano, Mario: “"Merecimiento de pena", "necesidad de pena” y teoría del delito", en, J. M. Silva S., (ed. española), B. Schunemann y J. De Figueiredo D., (coords), en "Fundamentos de un sistema europeo del Derecho Penal". Libro homenaje a Claus Roxin, Ed. Española, Barcelona, 1995.

Romeo C., Carlos: El médico y el Derecho Penal. I. La actividad curativa. (Licitud y responsabilidad penal), Barcelona, 1981.

Romeo C., Carlos: "La reforma penal del aborto: límite mínimo, figuras delictivas y sistema de las indicaciones", en J. Cerezo M. y otros. Presupuestos para la reforma penal. Centro de Estudios Criminológicos, Universidad de la Laguna, La Laguna, 1992.

Romeo C., Carlos: El derecho y la bioética ante los límites de la vida humana, Madrid, 1994.

Romeo C., Carlos: "Genética y derecho penal: los delitos de lesiones al feto y relativos a las manipulaciones genéticas”, en: Revista Brasileira de Ciencias Criminais, 4, N 16, 1996.

Romeo C., Carlos: Del gen al derecho, Bogotá, 1996.

Romeo C., Carlos: "Las investigaciones sobre el genoma humano y sus implicaciones para el Derecho: la intervención del Derecho Penal", en, el mismo (ed.): Dogmática penal, política criminal y criminología en evolución, Granada, 1997.

Romeo C., Carlos: "El diagnóstico preimplantatorio y pre natal, el consejo genético y la terapia génica", en, del mismo: Las transformaciones del derecho penal en un mundo en cambio, Tomo II, Arequipa, 2004 (a).

Romeo C., Carlos: Los delitos contra la vida y la integridad personal y los relativos a la manipulación genética, Granada, 2004 (b).

Ropero C., Julia: "La insuficiencia del sistema de indicaciones en el delito de aborto", en Anuario de Derecho Penaly Ciencias Penales., 2003.

Rostand, Jean: El correo de un biólogo, Madrid, 1970.

Roxin, Claus: "La propuesta minoritaria del Proyecto Alternativo", en, del mismo: Problemas básicos del derecho penal, Madrid, 1976.

Roxin, Claus: "El desarrollo del derecho sobre el aborto en la República Federal de Alemania", en Revista Jurídica de Cataluña, 1980.

Roxin, Claus: Derecho Penal, P. G., Tomo I, Madrid, 1997.

Roxin, Claus: "Las causas de justificación y de exculpación y su delimitación de otras causas de exclusión de la pena”, en, del mismo: Dogmática penal y política criminal, Lima, 1998 (a).

Roxin, Claus: "El estado de necesidad exculpante según el art. 35 CP.”, en, del mismo: Dogmática penal y politica criminal, Lima, 1998 (b). 
Horvitz y Soto - Consideraciones críticas sobre la regulación del delito de aborto...

Roxin, Claus: "La protección de la vida humana mediante el Derecho Penal", en: Dogmática y Ley Penal. Libro Homenaje a Enrique Bacigalupo, T. II, Madrid, 2004.

Ruiz M., Alfonso: “El aborto: problemas constitucionales”, Madrid, 1990.

Sanhueza R., Juana: “Tratamiento Jurídico del aborto terapéutico", en Revista de Derecho de la Universidad de Concepción, $\mathrm{N}^{\circ}$ 187, 1990.

Santana Paez, Emelina / Senent Martínez, Santiago: "De las lesiones al feto", en: M. Cobo del R. (dir.), "Comentarios al Código Penal, Madrid, 1999.

Sanz M., Angel: "Presupuestos para la reforma de los delitos contra la vida", en Anuario de Derecho Penaly Ciencias Penales, 1995.

Schepeler R., Manuel: El delito de aborto, Santiago, Talca, 1967.

Schünemann, Bernd: "La Política Criminal y el Sistema de Derecho Penal", en: Anuario de Derecho Penaly Ciencias Penales, 1991.

Schünemann, Bernd: “La función de delimitación de injusto y culpabilidad”, en, J. M. Silva S. (ed. española): cit.

Serna, P. / Toller, F.: La interpretación constitucional de los derechos fundamentales. Una alternativa a los conflictos de derechos, ed. La Ley S A, Buenos Aires, 2000.

Silva S., Jesús María: "La dimensión temporal del delito y los cambios de "status" jurídico - penal del objeto de la acción”, en G. Quintero O. y F. Morales P. (eds.): El nuevo Derecho penal español. Estudios penales en memoria del Profesor José Manuel Valle Muñiz, Pamplona, 2001.

Singer, Peter: Ética práctica, 2 ed., Editorial Ariel, Gran Bretaña, 1995.

Singer, Peter: Repensar la vida y la muerte. El derrumbe de nuestra ética tradicional, Barcelona - Buenos Aires, 1997.

Smart, Carol: "La mujer en el discurso jurídico", en E. Larrauri (comp.) Mujeres, Derecho penal y criminología, Siglo XXI Editores, Madrid, 1994.

Solozábal E., Juan José: "La igualdad en la aplicación de la ley", en Homenaje al Profesor Dr. Gonzalo Rodriguez. Mourullo, Madrid, 2005.

Steiner, Udo: "La controversia constitucional en Alemania sobre la regulación penal del aborto", en Revista Española de Derecho Constitucional, N 37, 1993

Stella, Federico: "Laicitá dello Stato: fede é diritto penale", G. Marinucci y E. Dolcini (a cura di), Diritto penale in trasformazione, Milán, 1985.

Stortoni, Luigi: "I principi generali della parte speciale", en: L. Stortoni y T. Padovani., "Diritto penale e fattispecie criminose", Bologna, 2001. 
REJ - Revista de Estudios de la Justicia - No 9 - Año 2007

Suárez, Gonzalo: en G. Rodríguez M. (dir.) y A. Jorge B. (coord.), en "Comentarios al Código Penal", Madrid, 1997.

Suárez M., Rodrigo Fabio: "El delito imposible de aborto en la jurisprudencia del Tribunal Supremo", en Anuario de Derecho Penaly Ciencias Penales, 1966.

Suárez M., Rodrigo Fabio: "El delito imposible de aborto con resultado muerte en la reciente jurisprudencia del Tribunal Supremo", en Estudios Penales y Criminológicos, IX, 1989.

Summerer, K.: "Contagio sessuale da virus VIH e responsabilitá penale dell? Aids-carrier", en Rivista Italiana di Diritto Penale e Procedura Penale, I, 2001.

Summerer, K.: "Le nuove frontiere Della tutela penale della vita prenatale", en Rivista Italiana di Diritto Penale e Procedura Penale, 4, 2003.

Stampa B., José M.: "El objeto material de los delitos contra la vida (límite mínimo)", en Anuario de Derecho Penal y Ciencias Penales, 1950.

Stratenwerth, Günther: Derecho Penal. P.G. 1, El hecho punible, Buenos Aires, 2005.

Teubner, Hans Georg: "Il trilemma regolativo. A proposito della polemica sui modelli giuridici post - Strumentali», en Febbrajo, Luhmann, Habermas, Teubner, Per un dibattito sulla <giuridificazione>, Politica del Diritto, año XVIII, 1, 1987.

Thomson J., Jarvis: "Defensa del aborto", en R. Dworkin, (comp.), ob. cit. y en M. Valdez (comp.) Controversias sobre el aborto, UNAM-FCE, México, 2001.

Tozzini, Carlos: Recensión a AA.VV. "II Jornadas ítalo-franco-luso-españolas de derecho penal. Interrupción voluntaria del embarazo. Responsabilidad penal objetiva, Ávila - Alcalá de Henares, 1982”, en Doctrina Penal, 1985.

Tozzini, Carlos: "La violación del secreto profesional médico en el aborto ", en Doctrina Penal, 1985.

Ugarte G., José Joaquín, en: J. J. Ugarte G. - J. Bustos R., "Debate sobre penalización o despenalización del aborto", en Revista de la Academia de Derecho, No2, 1993.

Ugarte G., José Joaquín: “El derecho de la vida. Bioética y Derecho”, Santiago, 2006.

Ugartemendia E., Juan Ignacio: La eficacia justificante de los derechos, Tirant lo Blanch, Valencia, 2003.

Valdez, Margarita: "Aborto y anticoncepción en México: las actitudes y los argumentos de la Iglesia Católica”, en Platts (comp.), Dilemas éticos, México, 1997.

Valdez, Margarita: “El problema del aborto: tres enfoques”, en R. Vázquez (comp.), Bioética y derecho. Fundamentos y problemas actuales, México, 1999.

Valdez, Margarita: “Aborto y personas", en M. Valdez (comp.): Controversias sobre el aborto, UNAM-FCE, México, 2001. 
Horvitz y Soto - Consideraciones críticas sobre la regulación del delito de aborto...

Valdez, Margarita: "Introducción”, en M. Valdez (comp.): Controversias sobre el aborto, UNAMFCE, México, 2001.

Valenzuela S., Jonatan: "Algunas consideraciones sobre el estatuto del embrión preimplantacional en Chile", en Revista de Estudios de la Justicia, № 3, 2003.

Valle M., José Manuel / González G., Marisé, "Utilización abusiva de técnicas genéticas y Derecho Penal", en Poder Judicial, 26, 1992.

Valle M., José Manuel, en: G. Quintero O. (dir) / F. Morales P. (coord.): Comentarios a la Parte Especial del Código Penal, $2^{\mathrm{a}}$ ed., Pamplona, 2004.

Vázquez, Rodolfo: Del aborto a la clonación. Principios de una bioética liberal, Fondo de Cultura Económica, México, 2004.

Vázquez, Rodolfo: "Comentarios a las propuestas bioético jurídicas del Luigi Ferrajoli”, en M. Carbonell y P. Salazar (eds.) Garantismo. Estudios sobre el pensamiento jurídico de Luigi Ferrajoli, Madrid, 2005.

Villoro, Luis: “¿Debe penalizarse el aborto?”, en M. Valdez (compilador), Controversias sobre el aborto, UNAM-FCE, México, 2001.

Vives, Francisco: Filosofía del Derecho, Imp. San Francisco, Santiago, 1957.

Vives A., Tomás: "Valoraciones ético sociales y Jurisprudencia Constitucional: el problema del aborto consentido", en, del mismo: La libertad como pretexto, Valencia, 1995 (a).

Vives A., Tomás: "Sobre la responsabilidad del médico en los supuestos de aborto consentido", en, del mismo: La libertad como pretexto, Valencia, 1995 (b).

Vives A., Tomás: «Ley y derechos fundamentales. (acerca del principio de legalidad en materia penal)", en, del mismo, La libertad como pretexto, Valencia, 1995 (c).

Volk, Klaus: Introduzione al Diritto Penale Tedesco, Padova, 1993.

Weisner, M.: El aborto inducido. Estudio antropológico en mujeres urbanas de bajo nivel socioeconómico. Tesis de Grado de Antropología. Fact. de Filosofía, Humanidades y Educación. Dpto. de Ciencias Sociológicas y Antropología. Universidad de Chile, Santiago, 1982.

Wertheiner, R.: "Comprender la controversia sobre el aborto", en M. M. Valdez, (compilador): Controversias sobre el aborto, México, 2001.

Wicclair Mark: "La controversia sobre el aborto y el reclamo de que este cuerpo es mío", en M. Valdez (compilador), Controversias sobre el aborto, México, 2001.

Zaffaroni, Eugenio Raúl: "El discurso feminista y el poder punitivo", en H. Birgin (comp.): Las trampas del poder punitivo. El Género del Derecho Penal, Buenos Aires, 2000.

Zoder, Isabel: "Reforma y regulación legal del aborto a la luz de la jurisprudencia, del Tribunal Constitucional Alemán", en Anuario de Derecho Penal y Ciencias Penales, 1996. 